\title{
The Impact of Carbon Dioxide Concentrations and Low to Adequate Photosynthetic Photon Flux Density on Growth, Physiology and Nutrient Use Efficiency of Juvenile Cacao Genotypes
}

\author{
Virupax C. Baligar ${ }^{1, *(\mathbb{D}}$, Marshall K. Elson ${ }^{1}$, Alex-Alan F. Almeida ${ }^{2} \mathbb{D}$, Quintino R. de Araujo ${ }^{2}$ (D) Dario Ahnert $^{2}$ \\ and Zhenli $\mathrm{He}^{3}$ (D) \\ 1 USDA-ARS-Beltsville Agricultural Research Center, Beltsville, MD 20705, USA; marshall.elson@usda.gov \\ 2 Department of Biological Science, State University of Santa Cruz, Ilhéus, BA 45650-000, Brazil; \\ alexalan@uesc.br (A.-A.F.A.); quintinoar@gmail.com (Q.R.d.A.); darioa@uesc.br (D.A.) \\ 3 IRREC, Institute of Food and Agriculture Sciience, University of Florida, Fort Pierce, FL 34945, USA; \\ zhe@ufl.edu \\ * Correspondence: V.C.Baligar@usda.gov; Tel.: +1-301-504-6492
}

Citation: Baligar, V.C.; Elson, M.K. Almeida, A.-A.F.; de Araujo, Q.R.; Ahnert, D.; He, Z. The Impact of Carbon Dioxide Concentrations and Low to Adequate Photosynthetic Photon Flux Density on Growth, Physiology and Nutrient Use Efficiency of Juvenile Cacao Genotypes. Agronomy 2021, 11, 397. https://doi.org/10.3390/ agronomy11020397

Academic Editor: Andrew Daymond

Received: 25 January 2021

Accepted: 19 February 2021

Published: 23 February 2021

Publisher's Note: MDPI stays neutral with regard to jurisdictional claims in published maps and institutional affiliations.

Copyright: (c) 2021 by the authors. Licensee MDPI, Basel, Switzerland. This article is an open access article distributed under the terms and conditions of the Creative Commons Attribution (CC BY) license (https:/ / creativecommons.org/licenses/by/ $4.0 /)$.

\begin{abstract}
Cacao (Theobroma cacao L.) was grown as an understory tree in agroforestry systems where it received inadequate to adequate levels of photosynthetic photon flux density (PPFD). As atmospheric carbon dioxide steadily increased, it was unclear what impact this would have on cacao growth and development at low PPFD. This research evaluated the effects of ambient and elevated levels carbon dioxide under inadequate to adequate levels of PPFD on growth, physiological and nutrient use efficiency traits of seven genetically contrasting juvenile cacao genotypes. Growth parameters (total and root dry weight, root length, stem height, leaf area, relative growth rate and net assimilation rates increased, and specific leaf area decreased significantly in response to increasing carbon dioxide and PPFD. Increasing carbon dioxide and PPFD levels significantly increased net photosynthesis and water-use efficiency traits but significantly reduced stomatal conductance and transpiration. With few exceptions, increasing carbon dioxide and PPFD reduced macro-micro nutrient concentrations but increased uptake, influx, transport and nutrient use efficiency in all cacao genotypes. Irrespective of levels of carbon dioxide and PPFD, intraspecific differences were observed for growth, physiology and nutrient use efficiency of cacao genotypes.
\end{abstract}

Keywords: water use efficiency; nutrient uptake; influx and transport; net photosynthesis; stomal conductance; relative growth rate

\section{Introduction}

Cacao (Theobroma cacao L) is native to the understory of the Amazonian forests of South America. As an understory plant, it has physiological characteristics similar to those of other shade-adapted species [1-4]. Growth and development of young cacao trees are better under shade; however, heavy shade is detrimental to growth and production of matured and older trees [5-8]. Cocoa is a $C_{3}$ species and prefers full sun, but is tolerant to moderate shading, due to its phenotypic plasticity for acclimatization in moderate shade conditions [9]. However, it does not tolerate dense shade, where pod production is low, even with adequate water levels and mineral nutrients availability in the soil. However, when the cacao tree is grown in full sun, there can be no limitations of water and mineral nutrients in the soil. In a long-term field study in Ghana, Amelonado cacao trees in full sun yielded three times as much as shaded trees; however, the economic life of unshaded trees did not last more than 10 years of intensive cropping due to infestation of diseases and insects and loss of needed soil nutrients [10]. There is no universal agreement on the 
degree of shade required to maximize production of cacao grown under different tropical ecosystems of the world [9,11-13].

In the major cacao growing regions of South and Central America, cacao is often grown as an understory plant in agroforestry systems (AFSs) $[9,14,15]$. In AFSs, various types of managed and unmanaged single and multi-strata systems are used where cacao is planted together with different types of shade trees, such as timber, fruit, firewood and leguminous trees, and in some cases tree species retained from thinned native forests [16-22]. In these management systems, cacao is subjected to various levels of low light quantity and quality at its canopy level depending upon the density of single or multi-strata shade trees, the nature and level of vegetative cover and the extent of shade tree pruning $[12,23,24]$. Shade trees in multi-strata AFSs are known to moderate the microclimatic conditions thereby improving cacao sustainability and providing other sources of income for farmers [6,17,24-26].

The amount of light falling on a cacao tree is known to affect its growth and yield, and moderate shade tends to reduce water and nutrient stress [6,12,27]. Optimum growth of young cacao plants was achieved at $20 \%$ to $30 \%$ of full sunlight $[1,28,29]$. However, maximum yield of adult plants requires limited shade or full sun especially in areas of ecosystems with heavy cloud cover [8]. Maximum photosynthesis in cacao leaves occurs at a PPFD of 350 to $550 \mu \mathrm{mol} \mathrm{m} \mathrm{m}^{-2} \mathrm{~s}^{-1}$, which is about $20 \%$ to $25 \%$ of the intensity of full sunlight [30-33]. In some young cacao genotypes, an increase of PPFD from 50 to $400 \mu \mathrm{mol} \mathrm{m}{ }^{-2} \mathrm{~s}^{-1}$ increased the net photosynthetic rate $\left(\mathrm{P}_{\mathrm{N}}\right)$ by about $50 \%$, but further increases (up to $1500 \mu \mathrm{mol} \mathrm{m}^{-2} \mathrm{~s}^{-1}$ ) had no effect, indicating that very little radiant energy is required to support efficient $\mathrm{P}_{\mathrm{N}}$ in cacao [30].

In shaded cacao plantations in Bahia Brazil, light intensity at noon above the cacao canopy ranged between $30 \%$ and $100 \%$ of full daylight [34]. Niether et al. [24] reported that cacao received $39 \%$ of full sunlight in an agroforestry system in Bolivia. Increasing PPFD from 65 to $1050 \mu \mathrm{mol} \mathrm{m} \mathrm{m}^{-2} \mathrm{~s}^{-1}$ reduced the growth and concentrations of several macro-micro nutrients in cacao [35]. Depending on the photosynthetic characteristics of the shade tree canopy and its density, different levels of blue and red light are absorbed and/or transmitted; therefore, light reaching field grown understory plants could be low in photosynthetically active radiation and with low $\mathrm{R} / \mathrm{FR}$ ratio [36,37].

The concentration of $\mathrm{CO}_{2}\left[\mathrm{CO}_{2}\right]$ in the atmosphere also affects growth of cacao. The present $\mathrm{CO}_{2}$ concentration is around $400 \mu \mathrm{mol} \mathrm{mol}{ }^{-1}$ and based on the Representative Concentration Pathway selected (RCP of 4.5 to 8.5) and future emission scenarios, $\mathrm{CO}_{2}$ could reach as high as 550 to $1370 \mu \mathrm{mol} \mathrm{mol}^{-1}$ by the end of the 21 st century $[38,39]$.

Overall, elevated $\left[\mathrm{CO}_{2}\right]$ increases plant growth (shoot and root biomass, leaf and root area, RGR) and physiological parameters (photosynthesis, water use efficiency, and nutrient uptake), however, the magnitude of such responses is dependent on availability of water and nutrients, and environmental variables such as light and temperature [1,30,35,40-46]. In cacao, increasing $\left[\mathrm{CO}_{2}\right]$ increased shoot, root and leaf growth, macro-micro nutrient use efficiency, photosynthesis and water use efficiency (WUE) traits; however, the magnitude of such responses to increased $\left[\mathrm{CO}_{2}\right]$ in cacao depended on the levels of PPFD and genotypes involved [30,35,46,47].

Soils in the cacao growing regions of the world are often acidic, infertile and invariably deficient in nitrogen $(\mathrm{N})$, potassium $(\mathrm{K})$, phosphorus $(\mathrm{P})$, calcium $(\mathrm{Ca})$, magnesium $(\mathrm{Mg})$, zinc $(\mathrm{Zn})$ and iron $(\mathrm{Fe})$, and that leads to severe essential nutrients deficiencies in cacao $[11,12,29,48-52]$. Increasing atmospheric $\left[\mathrm{CO}_{2}\right]$ coupled with low soil fertility and low irradiance subject cacao to severe nutrient stress and results in decline of yield potentials. Cacao has considerable genetic variation in morphological and physiological traits [4,53-55]. Such traits could be exploited in the selection of genotypes that have higher essential nutrient use efficiency under these abiotic stresses to generate cultivars more adapted to these conditions. Interactions between genotype and environmental factors may allow some genotypes to perform better in changing PPFD and $\mathrm{CO}_{2}$ conditions. The objectives of this research were to assess the influence of ambient and elevated levels of $\left[\mathrm{CO}_{2}\right]$ and low to adequate photosynthetic photon density (PPFD) on the growth, and phys- 
iological traits and macro-micro nutrient uptake, influx and transport and use efficiency in seven genetically contrasting cacao genotypes.

\section{Materials and Methods}

\subsection{Cacao Genotypes}

In total, 7 cacao genotypes (Catongo, Coca 3370/5, CCN 51, Amaz 15, LCT EEN 37/A, $\mathrm{Na} 33$ and SCA 6) were used for this study. Pods of these genotypes were received from MARS Center for Cocoa Science (MCCS) Almirante, Itajuipe, Bahia, Brazil. Catongo is from the lower Amazon region of Brazil; Amaz 15, NA 33 and SCA 6 are from the upper Amazon region of Peru; whereas LCT EEN 37A and Coca 3370/5 are from the upper Amazon region of Ecuador; and CCN 51 is a hybrid from Ecuador. These genotypes have been widely distributed in most of the cacao producing countries and some have been commonly used as parental or as cultivars in cacao breeding programs. Genetic background, origin and diseases resistance of these genotypes are covered in Bartley [56], Turnbull and Hadley [57], and Ahnert and Eskes [58]. Seeds were produced by self-pollination of plants. In the case of self-incompatible plants, they were obtained by the mixture of Herrania and cacao pollen, which helps to break self-incompatibility. Therefore, the self-pollinated family plants generated by such seeds have, on an average, similar traits to the parents, in this case, clonal cuttings. Findings of this study had a good scientific interest, showing differences between different genetic populations.

\subsection{Plants and Growth Medium}

Growth medium was prepared containing sand: perlite: peat moss (2:2:1 volume) supplemented with essential nutrients (mg/kg) $600 \mathrm{~N}, 600$ P, $240 \mathrm{~K}, 1012 \mathrm{Ca}, 309 \mathrm{Mg}, 500$ $\mathrm{S}, 119 \mathrm{Fe}, 0.7 \mathrm{~B}, 17.5 \mathrm{Mn}, 7 \mathrm{Cu}, 7 \mathrm{Zn}$, and $0.35 \mathrm{Mo}$. Nutrients were applied as Osmocote 18-6-12 (The Scotts Company, Marysville, Ohio, USA), triple superphosphate, urea, calcium sulphate, dolomitic lime and Scott's Micromix. Cacao seeds were removed from the pods, surface-sterilized with $10 \%$ bleach for $2 \mathrm{~min}$, rinsed twice in Deionized-water, then soaked in $90 \%$ ethanol for $2 \mathrm{~min}$ and rinsed twice in DI water. Seeds were germinated on sterile moist filter paper for $48 \mathrm{~h}$ at $25{ }^{\circ} \mathrm{C}$. Seeds with $2 \mathrm{~mm}$ radicle were planted in $3.8 \mathrm{~L}$ black plastic pots with adequate bottom drainage containing $2.2 \mathrm{~kg}$ of the growth mixture. One seedling was planted in each pot. Soil moisture was maintained near field capacity $(-33 \mathrm{kPa})$ by adding water every other day. An initial plant harvest was collected at 21 days after planting. The remaining plants were grown for additional 90 days.

\section{3. $\mathrm{CO}_{2}$ and PPFD Treatments}

The experiment was conducted in two glasshouses $\left(18 \mathrm{~m}^{2}\right.$ each) at Beltsville, MD and plants were grown with day/night temperatures of $30 / 28^{\circ} \mathrm{C}$. In the first glasshouse, ambient $\left[\mathrm{CO}_{2}\right]$ of $400 \pm 50 \mu \mathrm{mol} \mathrm{mol}^{-1}$ was maintained and in the second glasshouse elevated $\left[\mathrm{CO}_{2}\right]$ of $700 \pm 50 \mu \mathrm{mol} \mathrm{mol}^{-1}$ was maintained throughout the growth period. In the second glasshouse if $\left[\mathrm{CO}_{2}\right]$ fell below $700 \mu \mathrm{mol} \mathrm{mol}{ }^{-1}$ a WMA4 $\mathrm{CO}_{2}$ analyzer (PP Systems, Amesbury, MA, USA) injected the desired amount of $\mathrm{CO}_{2}$. After 55 days of growth, plants were swapped from one glasshouse to the other and $\left[\mathrm{CO}_{2}\right]$ levels were readjusted in each glasshouse as per the treatments. Within each glasshouse, electrical fans continuously circulated the air at an air speed of $0.5 \mathrm{~m} \mathrm{~s}^{-1}$ over the plants. Daytime air temperatures were maintained for $12 \mathrm{~h}$ per day beginning at $6 \mathrm{AM}$. The greenhouses transmitted approximately $60 \%$ of the incident PPFD daily. A data logger (21x, Campbell Scientific, Logan, UT, USA) recorded the PPFD, temperature and $\left[\mathrm{CO}_{2}\right]$ in both glasshouses at 30-s intervals.

In both glasshouses, plants were grown at three levels of photosynthetic photon flux density (PPFD) $\left(100 \pm 20,200 \pm 20\right.$ and $\left.400 \pm 20 \mu \mathrm{mol} \mathrm{m}^{-2} \mathrm{~s}^{-1}\right)$. To achieve these three levels of irradiance, mini-chambers were constructed with $2 \mathrm{~cm}(3 / 4$ inch) diameter PVC pipe with overall dimensions of $114 \mathrm{~cm} \mathrm{~W} \times 119 \mathrm{~cm} \mathrm{~L} \times 81 \mathrm{~cm} \mathrm{H}\left(45^{\prime \prime} \times 47^{\prime \prime} \times 32^{\prime \prime}\right)$. To achieve three different levels of PPFD, the tops and sides of the mini chambers were 
covered with three types of plastic mesh shade cloth: a single-ply of $70 \%$ smoke blue sun screen fabric (Easy Gardener, Waco TX) for low PPFD $\left(100 \mu \mathrm{mol} \mathrm{m}^{-2} \mathrm{~s}^{-1}\right)$, a single-ply of black fiberglass window screen (New York Wire, Mt. Wolf, PA, USA) for medium PPFD $\left(200 \mu \mathrm{mol} \mathrm{m}^{-2} \mathrm{~s}^{-1}\right)$ and a single-ply of $22 \%$ white shade cloth (National Tool Grinding, Inc, Erie, PA, USA) for high PPFD $\left(400 \mu \mathrm{mol} \mathrm{m} \mathrm{m}^{-2} \mathrm{~s}^{-1}\right)$. Each mini chamber was covered with mesh shade cloth so they have full air exchange with the environment. In each mini chamber the plants were rotated once per week to keep the light exposures consistent. The light levels in each mini chamber were measured at mid-day with a LI-190S quantum sensor (Li-Cor Inc., Lincoln, NE, USA). All experimental units were replicated three times and each experimental unit had a control pot with no plant in order to quantify evaporation.

\subsection{Determination of Plant Physiological Parameters}

A week before plant harvest, net photosynthesis $\left[\mathrm{P}_{\mathrm{N}}, \mu \mathrm{mol} \mathrm{CO} \mathrm{Cm}^{-2} \mathrm{~s}^{-1}\right]$, stomatal conductance $\left[\mathrm{gs}, \mathrm{mmol} \mathrm{H}_{2} \mathrm{O} \mathrm{m}^{-2} \mathrm{~s}^{-1}\right.$ ], internal leaf $\mathrm{CO}_{2}\left[\mathrm{Ci}, \mu \mathrm{mol} \mathrm{mol}{ }^{-1}\right]$ and rate of transpiration $\left[\mathrm{E}, \mathrm{mmol} \mathrm{H}_{2} \mathrm{O} \mathrm{m}^{-2} \mathrm{~s}^{-1}\right.$ ] were measured on the fully expanded sixth leaf from top of each plant using a CIRAS-2 Portable Photosynthesis System (PP Systems, Amesbury, MA, USA). The artificial light source was adjusted to the PPFD of the treatments (100, 200 and $400 \mu \mathrm{mol} \mathrm{m}{ }^{-2} \mathrm{~s}^{-1}$ ). The $\mathrm{CO}_{2}$ flux was adjusted to 400 or $700 \mu \mathrm{mol} \mathrm{mol}^{-1}$ depending on treatment. The leaf chamber temperature was constant at $30^{\circ} \mathrm{C}$. Readings were recorded after 15 min of equilibration. A SPAD meter (Konica Minolta Chlorophyll Meter, Model 502, Ramsey, NJ, USA) was used to determine SPAD index which could be useful to estimate the chlorophyll content of the leaves.

Water Use Efficiency (WUE) was determined by the following equations:

Total Water Use Efficiency, WUE $E_{\text {Total }}=g$ shoots dry wt. plant ${ }^{-1} / \mathrm{g} \mathrm{H}_{2} \mathrm{O}$ transpired plant $^{-1}$ over 90 days of growth

Instantaneous water use efficiency, $W U E_{\text {Inst }}=P_{N} / E, \mu \mathrm{mol} \mathrm{CO} 2 / \mathrm{mmol} \mathrm{H}_{2} \mathrm{O}$

Intrinsic water use efficiency, WUE Intr $=P_{N} / g s, \mu \mathrm{mol} \mathrm{CO} / \mathrm{mmol} \mathrm{H} \mathrm{C}_{2} \mathrm{O}$

Where $P_{N}\left(\mu \mathrm{mol} \mathrm{CO} \mathrm{m}^{-2} \mathrm{~s}^{-1}\right)$ is net photosynthetic rate, $E\left(\mathrm{mmol} \mathrm{H}_{2} \mathrm{O} \mathrm{m}^{-2} \mathrm{~s}^{-1}\right)$ is transpiration rate, and $g s\left(\mathrm{mmol} \mathrm{H}_{2} \mathrm{O} \mathrm{m}^{-2} \mathrm{~s}^{-1}\right)$ is stomatal conductance. These parameters were obtained from CIRAS-2 portable photosynthesis system measurements.

\subsection{Determination of Plant Growth Parameters}

After a growth period of 90 days, plants were harvested. Shoots were divided into stems and leaves and weighed. Total leaf area $\left(\mathrm{cm}^{2}\right)$ was measured using a LI-3100 leaf area meter (Li-Cor Inc., Lincoln, NE, USA). Shoots were washed in deionized water, freezedried and dry weight was recorded. The roots were removed from the soil, washed, blotted dry and weighed. Root lengths $\left(\mathrm{cm}_{\text {plant }}{ }^{-1}\right)$ were determined with a Comair Root Length Scanner (Hawker de Haviland, Melbourne, Victoria, Australia) and the roots were oven-dried at $70^{\circ} \mathrm{C}$ for 5 days and the dry weights were recorded.

Additional growth parameters were calculated by the following formulas:

Leaf area ratio $\left(\mathrm{LAR}, \mathrm{cm}^{2} / \mathrm{g}\right)=$ [total leaf area, $\mathrm{cm}^{2} /$ shoot+ root dry $\mathrm{wt}, \mathrm{g}$ ] Specific Leaf Area (SLA, $\mathrm{cm}^{2} / \mathrm{g}$ ) = [Total leaf area/plant, $\mathrm{cm}^{2} /$ Total leaf dry wt./plant, $\mathrm{g}$ ] Leaf mass/unit leaf area (LMA, $\left.\mathrm{g} / \mathrm{cm}^{2}\right)=[1 / \mathrm{SLA}]$

Root/shoot ratio $(\mathrm{R} / \mathrm{S})=[\mathrm{Wr} / \mathrm{Ws}]$, where Wr is root dry wt. and Ws is shoot dry wt. Root Radius $(\mathrm{RR}, \mathrm{cm})=(\mathrm{RFW} / \mathrm{RL} \times \pi)^{1 / 2}$ where RFW is root fresh wt. $\left(\mathrm{cm}^{3}\right)$

Relative growth rate $\left(R G R, g^{-1}\right.$ day $\left.^{-1}\right)=\left[\ln \left(\mathrm{Wt}_{2} / \mathrm{Wt}_{1}\right) /\left(\mathrm{T}_{2}-\mathrm{T}_{1}\right)\right]$, where $\mathrm{Wt}$ is total wt. (shoot+root), $\mathrm{T}$ is time in days, subscripts 1 and 2 refer to initial and final plant harvest.

Net assimilation rate $\left(\mathrm{NAR}, \mathrm{g} \mathrm{cm}^{-2} \mathrm{day}^{-1}\right)=[\mathrm{RGR} / \mathrm{LAR}]$

\subsection{Determination of Nutrient Uptake Parameters}

Dried stems and leaves were ground together to pass through a $1 \mathrm{~mm}$ sieve and sent to University of Florida, Indian River Research and Education Center (UF-IRREC), Fort Pierce, FL, USA. for macro-micro nutrient analysis. Plant samples of $0.4 \mathrm{~g}$ were digested in $5 \mathrm{~mL}$ of concentrated nitric acid $(14 \mathrm{~N})$, and macro-micro nutrient concentrations in 
the digested solutions were determined by using inductively coupled plasma optical emission spectrometry (ICPOES, Ultima JY Horiba Inc. Edison, NJ, USA) [59]. Total N in the plant tissue was analyzed by combustion method using a CN Analyzer (Vario MAX $\mathrm{CN}$ Elementar Analysensysteme GmbH, Hanau, Germany) [60].

Nutrient uptake (U), influx (IN), transport (TR) and nutrient use efficiency ratios (ER) were calculated using the following formulas:

Uptake $(\mathrm{U})=($ Conc. of any given element $) \times$ shoot dry wt.

Influx $(\mathrm{IN})=\left[\left(\mathrm{U}_{2}-\mathrm{U}_{1}\right) /\left(\mathrm{T}_{2}-\mathrm{T}_{1}\right)\right]\left[\left(\ln \mathrm{Wr}_{2}-\ln \mathrm{nr}_{1}\right) /\left(\mathrm{Wr}_{2}-\mathrm{Wr}_{1}\right)\right]$, where U refers to elemental content in shoot (mmol/plant), $\mathrm{T}$ is time in seconds, $\mathrm{Wr}$ is root dry wt., and subscripts 1 and 2 refer to initial and final plant harvest times.

Transport $(\mathrm{TR})=\left[\left(\mathrm{U}_{2}-\mathrm{U}_{1}\right) /\left(\mathrm{T}_{2}-\mathrm{T}_{1}\right)\right]\left[\left(\operatorname{lnWs}_{2}-\ln W \mathrm{~s}_{1}\right) /\left(\mathrm{Ws}_{2}-W \mathrm{~s}_{1}\right)\right]$, where Ws is shoot dry weight.

Nutrient Use Efficiency (NUE) = [mg of Ws/mg of any given element in shoot]

\subsection{Statistical Analysis}

Experiment was split plot design with $\left[\mathrm{CO}_{2}\right]$ as main plots, PPFD as subplots and genotypes as sub-sub plots and experimental units were replicated three times. All data were analyzed for statistical significance by ANOVA in SAS (Ver. 9.3, SAS Institute, Cary, NC, USA).

\section{Results and Discussion}

\subsection{Growth Traits}

Irrespective of $\left[\mathrm{CO}_{2}\right]$ and PPFD, significant intraspecific differences between cacao genotypes were observed for total and root wt., root length, stem height, leaf area, specific leaf area, relative growth rate (RGR) and net assimilation rates (NAR) (Table 1). Overall, Amaz 15 genotype had higher total and root growth parameters than any of the other genotypes studied. Genetic, physiological and morphological determinants and their interactions with environmental variables such as levels of PPFD and $\left[\mathrm{CO}_{2}\right]$ profoundly influence the growth, development and nutrient use efficiency of cacao $[9,30,35,46]$. Variation in morphological characteristics among cacao genotypes has been reported [4,53-55] and these morphological characteristics are known to be influenced by levels of PPFD and $\left[\mathrm{CO}_{2}\right][1,13,35,45,46,61]$.

Table 1. The effect of $\left[\mathrm{CO}_{2}\right]$ and photosynthetic photon flux density (PPFD) on shoot and root growth, leaf growth, relative growth rate (RGR) and net assimilation rate (NAR) of seven cacao genotypes.

\begin{tabular}{|c|c|c|c|c|c|c|c|c|c|c|}
\hline $\begin{array}{c}\mathrm{CO}_{2} \\
(\mu \mathrm{mol} \\
\left.\mathrm{mol}^{-1}\right)\end{array}$ & $\begin{array}{l}\text { PPFD } \\
(\mu \mathrm{mol} \\
\mathrm{m}^{-2} \\
\left.\mathrm{~s}^{-1}\right)\end{array}$ & $\begin{array}{l}\text { Total } \\
\text { Dry } \\
\text { Weight } \\
\text { (g/plant) }\end{array}$ & $\begin{array}{l}\text { Root } \\
\text { Dry } \\
\text { Weight } \\
\text { (g/plant) }\end{array}$ & $\begin{array}{l}\text { Root/ } \\
\text { Shoot } \\
\text { Ratio }\end{array}$ & $\begin{array}{l}\text { Stem } \\
\text { Height } \\
\text { (cm/plant) }\end{array}$ & $\begin{array}{l}\text { Total } \\
\text { Root } \\
\text { Length } \\
\text { (cm/plant) }\end{array}$ & $\begin{array}{l}\text { Leaf } \\
\text { Area } \\
\left(\mathrm{cm}^{2} / \text { plant }\right)\end{array}$ & $\begin{array}{c}\text { Specific } \\
\text { Leaf } \\
\text { Area } \\
\left(\mathrm{cm}^{2}\right. \\
\left.\mathrm{g}^{-1}\right)\end{array}$ & $\begin{array}{c}\text { RGR } \\
\left(\mathrm{g} \mathrm{g}^{-1}\right. \\
\left.\mathrm{d}^{-1}\right) \\
\left(\times 10^{-2}\right)\end{array}$ & $\begin{array}{c}\text { NAR } \\
\left(\mathrm{g} \mathrm{cm}^{-2}\right. \\
\left.\mathrm{d}^{-1}\right) \\
\left(\times 10^{-4}\right)\end{array}$ \\
\hline \multicolumn{11}{|c|}{ Catongo } \\
\hline \multirow[t]{3}{*}{400} & 100 & 7.59 & 0.91 & 0.136 & 34.33 & 3594 & 1712 & 316.8 & 2.899 & 1.287 \\
\hline & 200 & 7.87 & 1.11 & 0.167 & 32.33 & 3642 & 1391 & 266.3 & 2.930 & 1.662 \\
\hline & 400 & 6.50 & 0.83 & 0.146 & 29.17 & 3342 & 1087 & 243.9 & 2.730 & 1.635 \\
\hline \multirow[t]{3}{*}{700} & 100 & 12.64 & 2.02 & 0.190 & 41.00 & 4265 & 2063 & 268.7 & 3.696 & 2.290 \\
\hline & 200 & 15.44 & 2.61 & 0.204 & 45.17 & 4787 & 2277 & 246.8 & 3.884 & 2.808 \\
\hline & 400 & 14.16 & 2.17 & 0.180 & 39.33 & 4566 & 1616 & 207.6 & 3.770 & 3.271 \\
\hline \multicolumn{11}{|c|}{ Coca 3370} \\
\hline \multirow[t]{3}{*}{400} & 100 & 7.28 & 1.06 & 0.174 & 30.50 & 2661 & 1499 & 300.1 & 2.884 & 1.414 \\
\hline & 200 & 10.89 & 1.61 & 0.172 & 34.50 & 4257 & 1926 & 264.8 & 3.336 & 1.886 \\
\hline & 400 & 13.34 & 1.80 & 0.155 & 35.33 & 4104 & 2225 & 245.1 & 3.558 & 2.156 \\
\hline \multirow[t]{3}{*}{700} & 100 & 12.78 & 1.70 & 0.154 & 38.00 & 4196 & 2396 & 279.9 & 3.318 & 1.827 \\
\hline & 200 & 19.87 & 2.31 & 0.129 & 48.67 & 5045 & 3454 & 267.9 & 3.758 & 2.167 \\
\hline & 400 & 21.07 & 2.33 & 0.116 & 44.00 & 4938 & 3479 & 244.9 & 3.829 & 2.296 \\
\hline
\end{tabular}


Table 1. Cont.

\begin{tabular}{|c|c|c|c|c|c|c|c|c|c|c|}
\hline $\begin{array}{c}\mathrm{CO}_{2} \\
(\mu \mathrm{mol} \\
\left.\mathrm{mol}^{-1}\right)\end{array}$ & $\begin{array}{c}\text { PPFD } \\
(\mu \mathrm{mol} \\
\mathrm{m}^{-2} \\
\left.\mathrm{~s}^{-1}\right)\end{array}$ & $\begin{array}{l}\text { Total } \\
\text { Dry } \\
\text { Weight } \\
\text { (g/plant) }\end{array}$ & $\begin{array}{c}\text { Root } \\
\text { Dry } \\
\text { Weight } \\
\text { (g/plant) }\end{array}$ & $\begin{array}{l}\text { Root/ } \\
\text { Shoot } \\
\text { Ratio }\end{array}$ & $\begin{array}{l}\text { Stem } \\
\text { Height } \\
\text { (cm/plant) }\end{array}$ & $\begin{array}{l}\text { Total } \\
\text { Root } \\
\text { Length } \\
\text { (cm/plant) }\end{array}$ & $\begin{array}{c}\text { Leaf } \\
\text { Area } \\
\left(\mathrm{cm}^{2} / \text { plant }\right)\end{array}$ & $\begin{array}{c}\text { Specific } \\
\text { Leaf } \\
\text { Area } \\
\left(\mathrm{cm}^{2}\right. \\
\left.\mathrm{g}^{-1}\right) \\
\end{array}$ & $\begin{array}{c}\text { RGR } \\
\left(\mathrm{g} \mathrm{g}^{-1}\right. \\
\left.\mathrm{d}^{-1}\right) \\
\left(\times 10^{-2}\right)\end{array}$ & $\begin{array}{c}\text { NAR } \\
\left(\mathrm{g} \mathrm{cm}^{-2}\right. \\
\left.\mathrm{d}^{-1}\right) \\
\left(\times 10^{-4}\right)\end{array}$ \\
\hline \multicolumn{11}{|c|}{ CCN 51} \\
\hline \multirow[t]{3}{*}{400} & 100 & 5.55 & 0.72 & 0.140 & 23.83 & 2072 & 1278 & 344.1 & 2.436 & 1.077 \\
\hline & 200 & 8.04 & 0.94 & 0.130 & 30.50 & 2735 & 1722 & 301.5 & 2.977 & 1.405 \\
\hline & 400 & 9.32 & 1.19 & 0.137 & 32.00 & 2752 & 1697 & 280.0 & 3.116 & 1.731 \\
\hline \multirow[t]{3}{*}{700} & 100 & 13.82 & 1.96 & 0.164 & 34.17 & 4205 & 2705 & 300.7 & 3.530 & 1.797 \\
\hline & 200 & 16.68 & 2.13 & 0.149 & 42.33 & 4552 & 3092 & 288.8 & 3.721 & 1.995 \\
\hline & 400 & 23.60 & 2.46 & 0.118 & 49.33 & 5925 & 3578 & 231.6 & 4.109 & 2.741 \\
\hline \multicolumn{11}{|c|}{ Amaz 15} \\
\hline \multirow[t]{3}{*}{400} & 100 & 8.45 & 1.01 & 0.135 & 32.83 & 3006 & 1706 & 284.3 & 3.105 & 1.542 \\
\hline & 200 & 11.66 & 1.53 & 0.149 & 34.00 & 4214 & 2212 & 271.3 & 3.457 & 1.911 \\
\hline & 400 & 10.50 & 1.21 & 0.128 & 30.33 & 3400 & 1765 & 248.8 & 3.215 & 1.878 \\
\hline \multirow[t]{3}{*}{700} & 100 & 19.90 & 2.78 & 0.163 & 48.17 & 5682 & 3270 & 262.3 & 4.043 & 2.473 \\
\hline & 200 & 23.84 & 2.97 & 0.141 & 54.50 & 5848 & 3616 & 241.9 & 4.229 & 2.780 \\
\hline & 400 & 27.58 & 3.99 & 0.168 & 53.67 & 6436 & 3120 & 192.9 & 4.401 & 3.896 \\
\hline \multicolumn{11}{|c|}{ LCT EEN 37A } \\
\hline \multirow[t]{3}{*}{400} & 100 & 3.51 & 0.42 & 0.145 & 15.50 & 1548 & 740 & 268.4 & 2.101 & 1.0221 \\
\hline & 200 & 4.99 & 0.51 & 0.113 & 21.50 & 1875 & 841 & 231.2 & 2.561 & 1.544 \\
\hline & 400 & 4.25 & 0.43 & 0.127 & 20.33 & 1833 & 708 & 215.1 & 2.287 & 1.426 \\
\hline \multirow[t]{3}{*}{700} & 100 & 15.64 & 1.73 & 0.124 & 39.50 & 4807 & 3155 & 288.4 & 3.909 & 1.978 \\
\hline & 200 & 16.32 & 2.07 & 0.142 & 39.83 & 4627 & 2481 & 237.4 & 3.923 & 2.594 \\
\hline & 400 & 18.81 & 2.09 & 0.125 & 44.00 & 5576 & 2731 & 210.9 & 4.099 & 2.858 \\
\hline \multicolumn{11}{|c|}{$\mathrm{Na} 33$} \\
\hline \multirow[t]{3}{*}{400} & 100 & 7.34 & 0.86 & 0.134 & 34.83 & 3008 & 1284 & 256.6 & 2.848 & 1.654 \\
\hline & 200 & 9.20 & 0.95 & 0.113 & 34.33 & 3541 & 1644 & 251.3 & 3.082 & 1.739 \\
\hline & 400 & 5.77 & 0.63 & 0.114 & 27.17 & 2522 & 925 & 236.3 & 2.515 & 1.575 \\
\hline \multirow[t]{3}{*}{700} & 100 & 8.95 & 0.85 & 0.103 & 36.00 & 2575 & 1666 & 264.6 & 3.335 & 1.793 \\
\hline & 200 & 21.51 & 2.80 & 0.144 & 53.33 & 5724 & 3009 & 225.9 & 4.292 & 3.058 \\
\hline & 400 & 24.04 & 2.61 & 0.122 & 54.00 & 6375 & 2852 & 186.6 & 4.431 & 3.753 \\
\hline \multicolumn{11}{|c|}{ SCA 6} \\
\hline \multirow[t]{3}{*}{400} & 100 & 6.81 & 0.77 & 0.126 & 28.67 & 2317 & 1418 & 293.2 & 3.207 & 1.560 \\
\hline & 200 & 6.77 & 0.80 & 0.134 & 27.17 & 2457 & 1235 & 257.9 & 3.189 & 1.744 \\
\hline & 400 & 9.46 & 1.13 & 0.140 & 29.00 & 3327 & 1412 & 221.4 & 3.564 & 2.391 \\
\hline \multirow[t]{4}{*}{700} & 100 & 14.64 & 1.97 & 0.156 & 44.50 & 4263 & 2297 & 258.4 & 4.085 & 2.624 \\
\hline & 200 & 18.22 & 2.30 & 0.146 & 46.33 & 4169 & 2696 & 237.0 & 4.322 & 2.918 \\
\hline & 400 & 22.68 & 2.93 & 0.147 & 51.00 & 5899 & 3194 & 222.1 & 4.549 & 3.337 \\
\hline & & & & & Significance & & & & & \\
\hline \multicolumn{2}{|c|}{ Genotype (G) } & $* *$ & $* *$ & $* *$ & $* *$ & $* *$ & $* *$ & $* *$ & $* *$ & $* *$ \\
\hline \multicolumn{2}{|c|}{$\left[\mathrm{CO}_{2}\right](\mathrm{C})$} & $* *$ & $* *$ & NS & $* *$ & $* *$ & $* *$ & $* *$ & $* *$ & $* *$ \\
\hline \multicolumn{2}{|c|}{ PPFD (P) } & $* *$ & $* *$ & NS & $* *$ & $* *$ & $*$ & $* *$ & $* *$ & $* *$ \\
\hline
\end{tabular}

$*{ }^{* *}$ Significant at 0.05 and 0.01 levels of probability, respectively. NS = Not significant.

In the current study with exception of root/shoot ratio, all the growth traits of shoots and roots in cacao genotypes were significantly influenced by the level of $\left[\mathrm{CO}_{2}\right]$. Irrespective of PPFD levels, increasing $\left[\mathrm{CO}_{2}\right]$ from 400 to $700 \mu \mathrm{mol} \mathrm{mol}^{-1}$ increased all growth traits except SLA which decreased with increasing $\left[\mathrm{CO}_{2}\right]$. In many perennial tropical legume cover crops Baligar et al. [62,63] reported that increasing $\left[\mathrm{CO}_{2}\right]$ from ambient $(400 \mu \mathrm{mol}$ $\mathrm{mol}^{-1}$ ) to elevated $\left(700 \mu \mathrm{mol} \mathrm{mol}^{-1}\right)$ increased growth traits (dry biomass of shoot, leaf and roots, RGR and NAR). Generally, $\mathrm{C}_{3}$ plants respond positively to increased $\left[\mathrm{CO}_{2}\right]$ above 370 $\mu \mathrm{mol} \mathrm{mol}{ }^{-1}$ [64-66]. In the current study, increasing $\left[\mathrm{CO}_{2}\right]$ significantly increased total leaf 
area in all the genotypes. Lahive et al. [46] reported increased leaf area in Amelonado cacao genotype grown at elevated $\left[\mathrm{CO}_{2}\right]$, however, in a recent study, Hebbar et al. [47] found no significant differences in leaf area between cacao grown at 400 and $700 \mu \mathrm{mol} \mathrm{mol}^{-1}$ $\left[\mathrm{CO}_{2}\right]$. In the current study, increasing $\left[\mathrm{CO}_{2}\right]$ from 400 to $700 \mu \mathrm{mol} \mathrm{mol}^{-1}$ increased average root dry weight and root length by 0.97 to $2.32 \mathrm{~g} \mathrm{plant}^{-1}$ and 2962 to $4974 \mathrm{~cm} \mathrm{plant}^{-1}$ respectively. At elevated $\left[\mathrm{CO}_{2}\right]$, it seems that allocation of carbon fixed by photosynthesis to the roots is as high as that to the shoots. Elevated $\left[\mathrm{CO}_{2}\right]$ often increases the R/S ratio and fine-root proliferation [43].

In all the cacao genotypes studied, all the growth parameters were significantly influenced by levels of PPFD. Shade tolerant species including cacao are known to respond positively to elevated $\left[\mathrm{CO}_{2}\right]$, however such enhanced growth response is also governed by light levels $[35,46,67,68]$. Irrespective of levels of $\left[\mathrm{CO}_{2}\right]$, increasing PPFD from 100 to $400 \mu \mathrm{mol} \mathrm{m} \mathrm{m}^{-2} \mathrm{~s}^{-1}$ increased growth traits (total and root weight, stem height, root length, total leaf area, RGR and NAR). However specific leaf area (SLA) was reduced with increasing PPFD indicating that increasing PPFD increases the thickness of the leaves. In cacao genotypes, heavier shade may increase leaf area [19]. Such an adaptation seems to maximize the photon capture capacity of the leaves [45]. Irrespective of $\left[\mathrm{CO}_{2}\right]$, increasing PPFD from 100 to $400 \mu \mathrm{mol} \mathrm{m} \mathrm{m}^{-2} \mathrm{~s}^{-1}$ increased average root weight and root length by 1.34 to $1.84 \mathrm{~g} \mathrm{plant}^{-1}$ and 3443 to $4357 \mathrm{~cm} \mathrm{plant}^{-1}$, respectively. This indicates an increased allocation of carbon fixed through photosynthesis to roots at higher PPFD. Aerial morphological characteristics could have great implications on the ability of plants to intercept and utilize solar radiation and these characteristics in cacao are influenced by level of irradiance $[1,9,13,35,45,61]$.

\subsection{Physiological and Water Use Efficiency Traits}

Significant intraspecific differences were observed for SPAD index, net photosynthesis $\left(\mathrm{P}_{\mathrm{N}}\right)$, stomatal conductance $(\mathrm{gs})$, internal $\mathrm{CO}_{2}(\mathrm{Ci})$ and transpiration (E) irrespective of levels of $\left[\mathrm{CO}_{2}\right]$ and PPFD (Table 2). Amaz 15 had higher $\mathrm{P}_{\mathrm{N}}$ than any other cacao genotype at all levels of $\left[\mathrm{CO}_{2}\right]$ and PPFD evaluated. This genotype also had the highest leaf area per plant. Increasing $\left[\mathrm{CO}_{2}\right]$ from ambient to $700 \mu \mathrm{mol} \mathrm{mol}{ }^{-1}$ has been shown to increase $\mathrm{P}_{\mathrm{N}}$ in $\mathrm{C}_{3}$ plants [44]. In the current study irrespective of PPFD levels, increasing $\left[\mathrm{CO}_{2}\right]$ from 400 to $700 \mu \mathrm{mol} \mathrm{mol}^{-1}$ resulted in a significant increase in $\mathrm{P}_{\mathrm{N}}$ of all cacao genotypes from an average of 2.47 to $3.41 \mu \mathrm{mol} \mathrm{CO} \mathrm{C}^{-2} \mathrm{~s}^{-1}$. In an earlier study with 1.5-year-old cacao plants, increasing $\left[\mathrm{CO}_{2}\right]$ from 370 to $680 \mu \mathrm{mol} \mathrm{mol}^{-1}$ resulted in a $33 \%$ increase in $\mathrm{P}_{\mathrm{N}}$ [30]. In cacao genotype Amelonado, increasing $\left[\mathrm{CO}_{2}\right]$ from 460 to $735 \mu \mathrm{mol} \mathrm{mol}^{-1}$ increased $\mathrm{P}_{\mathrm{N}}$ by 56\% [46]. Recently Hebbar et al. [47] in an open top camber study with cacao reported an increase in $\mathrm{P}_{\mathrm{N}}$ of $29 \%$ by increasing $\left[\mathrm{CO}_{2}\right]$ from 400 to $700 \mu \mathrm{mol} \mathrm{mol}^{-1}$. Increasing photosynthesis with increasing $\left[\mathrm{CO}_{2}\right]$ reported in these studies is typical of responses observed in other $\mathrm{C}_{3}$ plants $[69,70]$.

Levels of aerial $\left[\mathrm{CO}_{2}\right]$ have significant effects on gs activity. In all the cacao genotypes studied, irrespective of PPFD levels, increasing $\left[\mathrm{CO}_{2}\right]$ from 400 to $700 \mu \mathrm{mol} \mathrm{mol}{ }^{-1}$ resulted in a significant reduction in gs from an average of 19.5 to $12.6 \mathrm{mmol} \mathrm{H}_{2} \mathrm{O} \mathrm{m}^{-2} \mathrm{~s}^{-1}$. In leaves of annual $\mathrm{C}_{3}$ plants, doubling of $\left[\mathrm{CO}_{2}\right]$ reduced gs by $34 \%$ [69]. In an earlier study with cacao genotypes, Baligar et al. [30] reported around a $65 \%$ reduction in gs by increasing $\left[\mathrm{CO}_{2}\right]$ from 370 to $700 \mu \mathrm{mol} \mathrm{mol}^{-1}$. Such a large decrease in gs led to a substantial reduction in $\mathrm{E}$, which could improve cacao water status and drought resistance. Elevated $\left[\mathrm{CO}_{2}\right]$ has been shown to reduce $E$ and gs in most $C_{3}$ plants [69]. However, Lahive et al. [46] reported that $\mathrm{CO}_{2}$ concentrations of ambient (average of $466 \mu \mathrm{mol} \mathrm{mol}^{-1}$ ) and elevated (average of $725 \mu \mathrm{mol} \mathrm{mol}^{-1}$ ) did not have an effect on gs in cacao genotype Amelonado. Stomatal conductance (gs) plays a vital role in regulating $\mathrm{P}_{\mathrm{N}}$, transpiration $(\mathrm{E})$, leaf temperature and plant water stress tolerance $[13,71,72]$.

Irrespective of the levels of PPFD, increasing $\left[\mathrm{CO}_{2}\right]$ from 400 to $700 \mu \mathrm{mol} \mathrm{mol}{ }^{-1} \mathrm{re}^{-}$ sulted in a significant reduction in transpiration (E) from an average of 0.267 to $0.172 \mathrm{mmol}$ $\mathrm{m}^{-2} \mathrm{~s}^{-1}$. A large decrease in gs, as observed in the current study, with increasing $\left[\mathrm{CO}_{2}\right]$ 
could lead to reduced $\mathrm{E}$ and such changes could improve water status and drought resistance of cacao. Baligar et al. [30] reported that increasing $\left[\mathrm{CO}_{2}\right]$ from 85 to $850 \mu \mathrm{mol} \mathrm{mol}^{-1}$ significantly decreased $\mathrm{E}$ from 0.66 to $0.16 \mathrm{mmol} \mathrm{m}^{-2} \mathrm{~s}^{-1}$ in three cacao genotypes.

It has been widely reported that maximum photosynthesis $\left(\mathrm{P}_{\mathrm{N}}\right)$ in cacao occurs at PPFD of 350 to $550 \mu \mathrm{mol} \mathrm{m}^{-2} \mathrm{~s}^{-1}$ [30-33]. The limited PPFD received at cacao canopy levels might be the reason for lower yields in agroforestry systems [73]. In the seven cacao genotypes in the current study, irrespective of $\left[\mathrm{CO}_{2}\right]$, increasing levels of PPFD from 100 to $400 \mu \mathrm{mol} \mathrm{m}^{-2} \mathrm{~s}^{-1}$ resulted in significant increases in $P_{\mathrm{N}}$ from an average of 2.67 to $3.41 \mu \mathrm{mol} \mathrm{m} \mathrm{m}^{-2} \mathrm{~s}^{-1}$. In an earlier study with three genetically differing cacao genotypes, Baligar et al. [30] reported that increasing PPFD from 50 to $400 \mu \mathrm{mol} \mathrm{m}{ }^{-2} \mathrm{~s}^{-1}$ significantly increased $\mathrm{P}_{\mathrm{N}}$. However, $\mathrm{P}_{\mathrm{N}}$ at $50 \mu \mathrm{mol} \mathrm{m} \mathrm{m}^{-2} \mathrm{~s}^{-1}$ of PPFD was about twothirds of the maximum $3 \mu \mathrm{mol} \mathrm{CO} \mathrm{m}^{-2} \mathrm{~s}^{-1}$ indicating that cacao needs very little radiant energy to support its $P_{N}$. Higher rates of $P_{N}$, thicker leaves and high rates of $E$ have been observed in certain cacao genotypes when grown in full sunlight rather than under shade [1]. Increasing PPFD from 100 to $400 \mu \mathrm{mol} \mathrm{m}^{-2} \mathrm{~s}^{-1}$ reduced specific leaf area from an average of 284.7 to $227.7 \mathrm{~cm}^{2} \mathrm{~g}^{-1}$, such increases in leaf thickness might contribute to higher $\mathrm{P}_{\mathrm{N}}$. However, exposure of leaves to extremely high light for longer periods may lead to photoinhibition and lower $\mathrm{P}_{\mathrm{N}}[34,41,42]$. Baligar et al. [35] reported that PPFD of $1050 \mu \mathrm{mol} \mathrm{m}{ }^{-2} \mathrm{~s}^{-1}$ was detrimental to shoot, root and leaf growth of cacao seedlings. In all the cacao genotypes studied irrespective of levels of $\left[\mathrm{CO}_{2}\right]$, increasing levels of PPFD from 100 to $400 \mu \mathrm{mol} \mathrm{m} \mathrm{m}^{-2} \mathrm{~s}^{-1}$ resulted in significant increases in gs and $\mathrm{E}$ from an average of 15.33 to $19.35 \mathrm{mmol} \mathrm{H}_{2} \mathrm{O} \mathrm{m}^{-2} \mathrm{~s}^{-1}$ and 0.215 to $0.258 \mathrm{mmol} \mathrm{H}_{2} \mathrm{O} \mathrm{m}^{-2} \mathrm{~s}^{-1}$, respectively. In an earlier short-term study, Baligar et al. [30] reported that the gs was not significantly affected by PPFD over the observed range of 50 to $400 \mu \mathrm{mol} \mathrm{m}^{-2} \mathrm{~s}^{-1}$; however, there was a slight increase in E, but the relationship between $\mathrm{E}$ and PPFD was not significant. Under artificial shade, the quality of the PPFD that reaches the canopy of cocoa leaves is very different from the quality of the PPFD that reaches the canopy of cocoa trees leaves grown in field conditions and shaded by tree species. In field conditions, there is an attenuation of both the intensity and the quality of the light available for cocoa photosynthesis, depending on the greater or lesser absorbance and/or transmittance of electromagnetic light, mainly in the blue and red bands, which crosses canopy strata of different shade tree species. Depending on the photosynthetic characteristics of the shade tree canopy, different levels of PPFD blue and red light are absorbed and/or transmitted, which can affect net photosynthesis differently from cocoa grown under artificial shade. Therefore, obtained results of $\mathrm{P}_{\mathrm{N}}$ are based on cacao genotypes subjected to ambient and elevated levels of $\left[\mathrm{CO}_{2}\right]$ under various levels of artificial shade.

Table 2. The effect of $\left[\mathrm{CO}_{2}\right]$ and photosynthetic photon flux density (PPFD) on photosynthesis and its components, and water use efficiency of seven cacao genotypes.

\begin{tabular}{|c|c|c|c|c|c|c|c|c|c|}
\hline $\begin{array}{c}\mathrm{CO}_{2} \\
(\mu \mathrm{mol} \\
\left.\mathrm{mol}^{-1}\right)\end{array}$ & $\begin{array}{c}\text { PPFD } \\
\left(\mu \mathrm{mol} \mathrm{m}^{-2}\right. \\
\left.\mathrm{s}^{-1}\right)\end{array}$ & $\begin{array}{l}\text { SPAD } \\
\text { Index }\end{array}$ & $\begin{array}{l}\text { Photosynthesis } \\
\qquad(\mu \mathrm{mol} \mathrm{CO} 2 \\
\left.\mathrm{m}^{-2} \mathrm{~s}^{-1}\right)\end{array}$ & $\begin{array}{c}\text { Stomatal } \\
\text { Conduc- } \\
\text { tance } \\
\left(\mathrm{mmol}^{2}\right. \\
\mathrm{H}_{2} \mathrm{O} \mathrm{m}^{-2} \\
\mathrm{~s}^{-1} \text { ) }\end{array}$ & $\begin{array}{c}\text { Internal } \\
\mathrm{CO}_{2}(\mu \mathrm{mol} \\
\left.\mathrm{mol}^{-1}\right)\end{array}$ & $\begin{array}{l}\text { Transpiration } \\
\text { (mmol } \\
\mathrm{H}_{2} \mathrm{O} \mathrm{m} \mathrm{m}^{-2} \\
\mathrm{~s}^{-1} \text { ) }\end{array}$ & $\begin{array}{c}\text { WUE }_{\text {Total }} \\
(\mathrm{g} \text { shoot/g } \\
\text { trans.) } \\
\left(\times 10^{-3}\right)\end{array}$ & $\begin{array}{c}\text { WUE Inst }^{¥} \\
(\mu \mathrm{mol} \\
\mathrm{CO}_{2} / \mathrm{mmol} \\
\left.\mathrm{H}_{2} \mathrm{O}\right)\end{array}$ & $\begin{array}{c}\text { WUE }_{\text {Intr }} \\
(\mu \mathrm{mol} \\
\mathrm{CO}_{2} / \mathrm{mmol} \\
\left.\mathrm{H}_{2} \mathrm{O}\right)\end{array}$ \\
\hline & \multicolumn{9}{|c|}{ Catongo } \\
\hline \multirow[t]{3}{*}{400} & 100 & 42.3 & 2.64 & 20.66 & 157.6 & 0.291 & 8.34 & 9.17 & 0.132 \\
\hline & 200 & 42.8 & 1.75 & 15.36 & 158.3 & 0.213 & 6.22 & 8.71 & 0.125 \\
\hline & 400 & 42.4 & 3.02 & 25.02 & 222.8 & 0.341 & 23.80 & 8.90 & 0.126 \\
\hline \multirow[t]{3}{*}{700} & 100 & 37.7 & 3.15 & 10.26 & 122.3 & 0.143 & 18.42 & 22.03 & 0.328 \\
\hline & 200 & 42.1 & 4.34 & 16.39 & 192.2 & 0.218 & 10.60 & 20.23 & 0.269 \\
\hline & 400 & 42.2 & 5.82 & 22.57 & 205.5 & 0.291 & 27.75 & 19.99 & 0.258 \\
\hline
\end{tabular}


Table 2. Cont.

\begin{tabular}{|c|c|c|c|c|c|c|c|c|c|}
\hline $\begin{array}{c}\mathrm{CO}_{2} \\
(\mu \mathrm{mol} \\
\left.\mathrm{mol}^{-1}\right)\end{array}$ & $\begin{array}{c}\text { PPFD } \\
(\mu \mathrm{mol} \\
\left.\mathrm{m}^{-2} \mathrm{~s}^{-1}\right)\end{array}$ & $\begin{array}{l}\text { SPAD } \\
\text { Index }\end{array}$ & $\begin{array}{l}\text { Photosynthesis } \\
(\mu \mathrm{mol} \mathrm{CO} \\
\left.\mathrm{m}^{-2} \mathrm{~s}^{-1}\right)\end{array}$ & $\begin{array}{c}\text { Stomatal } \\
\text { Conduc- } \\
\text { tance } \\
\left(\mathrm{mmol}^{-}\right. \\
\mathrm{H}_{2} \mathrm{O} \mathrm{m}^{-2} \\
\left.\mathrm{~s}^{-1}\right)\end{array}$ & $\begin{array}{c}\text { Internal } \\
\mathrm{CO}_{2} \\
(\mu \mathrm{mol} \\
\left.\mathrm{mol}^{-1}\right)\end{array}$ & $\begin{array}{l}\text { Transpiratic } \\
(\text { mmol } \\
\mathrm{H}_{2} \mathrm{O} \mathrm{m}^{-2} \\
\left.\mathrm{~s}^{-1}\right)\end{array}$ & $\begin{array}{l}\text { nWUE }_{\text {Total }} \\
\text { (g shoot/g } \\
\text { trans.) } \\
\left(\times 10^{-3}\right)\end{array}$ & $\begin{array}{c}\text { WUE } E_{\text {Inst }} \\
¥(\mu \mathrm{mol} \\
\mathrm{CO}_{2} / \mathrm{mmol} \\
\left.\mathrm{H}_{2} \mathrm{O}\right)\end{array}$ & $\begin{array}{c}\mathrm{WUE}_{\text {Intr }} \\
(\mu \mathrm{mol} \\
\mathrm{CO}_{2} / \mathrm{mmol} \\
\left.\mathrm{H}_{2} \mathrm{O}\right)\end{array}$ \\
\hline & \multicolumn{9}{|c|}{ Coca 3370} \\
\hline \multirow[t]{3}{*}{400} & 100 & 43.8 & 3.21 & 20.19 & 106.4 & 0.284 & 9.53 & 11.51 & 0.163 \\
\hline & 200 & 40.2 & 2.17 & 15.88 & 128.3 & 0.218 & 5.51 & 9.85 & 0.140 \\
\hline & 400 & 40.2 & 3.27 & 24.96 & 127.1 & 0.321 & 7.34 & 10.02 & 0.133 \\
\hline \multirow[t]{4}{*}{700} & 100 & 41.9 & 2.63 & 12.07 & 283.1 & 0.170 & 19.77 & 16.18 & 0.233 \\
\hline & 200 & 46.4 & 3.83 & 14.61 & 190.1 & 0.207 & 99.22 & 19.10 & 0.267 \\
\hline & 400 & 40.0 & 3.46 & 12.66 & 190.8 & 0.175 & 30.54 & 19.87 & 0.274 \\
\hline & \multicolumn{9}{|c|}{ CCN 51} \\
\hline \multirow[t]{3}{*}{400} & 100 & 42.1 & 2.19 & 18.02 & 236.6 & 0.267 & 12.29 & 9.47 & 0.146 \\
\hline & 200 & 42.9 & 1.85 & 12.58 & 132.9 & 0.179 & 5.26 & 9.64 & 0.139 \\
\hline & 400 & 39.4 & 1.80 & 20.13 & 351.2 & 0.285 & 5.91 & 5.96 & 0.085 \\
\hline \multirow[t]{4}{*}{700} & 100 & 42.2 & 2.52 & 8.47 & 189.3 & 0.129 & 15.61 & 19.58 & 0.296 \\
\hline & 200 & 45.9 & 4.52 & 14.21 & 135.7 & 0.192 & 18.26 & 22.71 & 0.313 \\
\hline & 400 & 42.3 & 3.99 & 14.88 & 182.0 & 0.198 & 38.23 & 20.17 & 0.268 \\
\hline & \multicolumn{9}{|c|}{ Amaz 15} \\
\hline \multirow[t]{3}{*}{400} & 100 & 44.4 & 3.14 & 22.26 & 126.6 & 0.299 & 10.87 & 10.78 & 0.149 \\
\hline & 200 & 40.3 & 2.90 & 17.77 & 81.1 & 0.238 & 6.12 & 12.22 & 0.166 \\
\hline & 400 & 39.5 & 3.44 & 22.41 & 132.3 & 0.308 & 7.33 & 11.19 & 0.154 \\
\hline \multirow[t]{4}{*}{700} & 100 & 40.7 & 3.74 & 12.44 & 161.5 & 0.171 & 15.20 & 21.94 & 0.306 \\
\hline & 200 & 43.0 & 4.31 & 14.00 & 109.7 & 0.187 & 11.49 & 23.31 & 0.325 \\
\hline & 400 & 38.7 & 4.25 & 16.57 & 222.2 & 0.216 & 18.20 & 20.15 & 0.270 \\
\hline & \multicolumn{9}{|c|}{$\begin{array}{c}\text { LCT EEN } \\
37 \mathrm{~A}\end{array}$} \\
\hline \multirow[t]{3}{*}{400} & 100 & 43.5 & 3.57 & 42.11 & 323.7 & 0.552 & 5.57 & 7.76 & 0.106 \\
\hline & 200 & 44.1 & 1.83 & 11.71 & 127.7 & 0.173 & 15.12 & 10.48 & 0.173 \\
\hline & 400 & 38.8 & 4.16 & 31.75 & 190.0 & 0.422 & 6.09 & 9.99 & 0.135 \\
\hline \multirow[t]{4}{*}{700} & 100 & 43.1 & 4.14 & 13.54 & 141.8 & 0.190 & 16.67 & 21.82 & 0.305 \\
\hline & 200 & 43.3 & 2.78 & 11.34 & 213.3 & 0.153 & 11.49 & 17.78 & 0.242 \\
\hline & 400 & 45.4 & 4.83 & 17.27 & 158.3 & 0.222 & 30.68 & 21.23 & 0.273 \\
\hline & \multicolumn{9}{|c|}{$\mathrm{Na} 33$} \\
\hline \multirow[t]{3}{*}{400} & 100 & 42.1 & 1.47 & 11.58 & 133.4 & 0.166 & 14.26 & 10.30 & 0.154 \\
\hline & 200 & 38.6 & 2.14 & 13.86 & 109.6 & 0.196 & 5.36 & 10.79 & 0.158 \\
\hline & 400 & 36.9 & 1.11 & 11.83 & 233.2 & 0.172 & 4.29 & 8.44 & 0.118 \\
\hline \multirow[t]{4}{*}{700} & 100 & 36.1 & 2.03 & 7.64 & 261.1 & 0.116 & 20.66 & 15.07 & 0.234 \\
\hline & 200 & 42.3 & 1.94 & 7.15 & 142.5 & 0.105 & 8.90 & 20.79 & 0.310 \\
\hline & 400 & 34.6 & 3.10 & 12.71 & 181.3 & 0.168 & 12.42 & 19.82 & 0.257 \\
\hline & \multicolumn{9}{|c|}{ SCA 6} \\
\hline \multirow[t]{3}{*}{400} & 100 & 44.8 & 1.51 & 10.70 & 153.6 & 0.157 & 9.25 & 9.32 & 0.136 \\
\hline & 200 & 42.6 & 1.77 & 13.65 & 150.2 & 0.194 & 8.32 & 9.08 & 0.130 \\
\hline & 400 & 43.7 & 2.92 & 26.40 & 177.2 & 0.334 & 6.07 & 8.74 & 0.113 \\
\hline \multirow[t]{3}{*}{700} & 100 & 43.3 & 1.39 & 4.73 & 235.9 & 0.073 & 18.85 & 19.17 & 0.320 \\
\hline & 200 & 41.7 & 2.41 & 9.35 & 239.7 & 0.132 & 12.83 & 17.48 & 0.249 \\
\hline & 400 & 36.2 & 2.51 & 11.72 & 246.3 & 0.158 & 29.97 & 16.22 & 0.217 \\
\hline \multicolumn{10}{|c|}{ Significance } \\
\hline \multirow{3}{*}{\multicolumn{2}{|c|}{$\begin{array}{c}\text { Genotype }(\mathrm{G}) \\
{\left[\mathrm{CO}_{2}\right](\mathrm{C})} \\
\text { PPFD }(\mathrm{P})\end{array}$}} & $*$ & $* *$ & $* *$ & NS & $* *$ & NS & NS & NS \\
\hline & & NS & $* *$ & $* *$ & NS & $* *$ & $* *$ & $* *$ & $* *$ \\
\hline & & $* *$ & $*$ & $* *$ & NS & $* *$ & NS & NS & NS \\
\hline
\end{tabular}

$*$,** Significant at 0.05 and 0.01 levels of probability, respectively. NS $=$ Not significant. ${ }^{*}$ Instantaneous water use efficiency, WUE $E_{\text {Inst }}=$ $\mathrm{P}_{\mathrm{N}} / \mathrm{E},\left(\mu \mathrm{mol} \mathrm{CO} 2 / \mathrm{mmol} \mathrm{H}_{2} \mathrm{O}\right)$; Intrinsic water use efficiency, WUE $\mathrm{Intr}=\mathrm{P}_{\mathrm{N}} / \mathrm{gs},\left(\mu \mathrm{mol} \mathrm{CO} \mathrm{CO}_{2} / \mathrm{mmol} \mathrm{H}_{2} \mathrm{O}\right)$. 
Intraspecific differences in WUE traits $\left(W U E_{T o t a l}, W U E_{\text {Inst }}\right.$ and WUE Intr $)$ between the cacao genotypes were observed but the differences were not significant (Table 2). Amaz 15 had the highest WUE $E_{\text {Inst }}$ and $W U E_{I n t r}$, which is a reflection of its high $\mathrm{P}_{\mathrm{N}}$ compared to the other cacao genotypes. In eight contrasting cacao genotypes, variations in $\mathrm{WUE}_{\text {Inst }}$ and $W U E_{\text {Intr }}$ were negatively related to specific leaf area [4]. In the current study, all three WUE traits increased with decreasing specific leaf area. In the seven cacao genotypes studied, increasing PPFD and $\left[\mathrm{CO}_{2}\right]$, increased WUE traits. Increasing $\left[\mathrm{CO}_{2}\right]$ from 400 to $700 \mu \mathrm{mol} \mathrm{mol}{ }^{-1}$ caused significant increases in all three water use efficiency traits

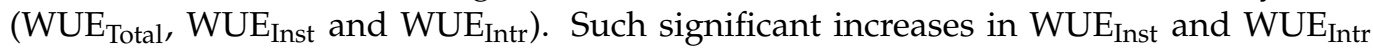
traits at elevated $\left[\mathrm{CO}_{2}\right]$ could be related to increased $\mathrm{P}_{\mathrm{N}}$ and reduced gs and $\mathrm{E}[13,74]$. Lahive et al. [46] reported significantly greater intrinsic water use efficiency (WUE $\mathrm{Intr}_{\mathrm{r}}$ ) in plants grown at elevated $\mathrm{CO}_{2}$ (average of $725 \mu \mathrm{mol} \mathrm{mol}^{-1}$ ) and related such an increase to higher $\mathrm{P}_{\mathrm{N}}$, as there was no difference in the measured gs between ambient and elevated $\mathrm{CO}_{2}$. In open top chambers, elevated $\left[\mathrm{CO}_{2}\right]$ up to $700 \mu \mathrm{mol} \mathrm{mol}{ }^{-1}$ increased $\mathrm{P}_{\mathrm{N}}$ by $27 \%$ and resulted in high cacao biomass accumulation, and thus improved whole plant WUE [47]. Further Hebbar et al. [47] concluded that higher WUE at elevated $\left[\mathrm{CO}_{2}\right]$ was due to high $\mathrm{P}_{\mathrm{N}}$ rather than reduced water loss through stomata $(\mathrm{E})$. In the current research with seven contrasting cacao genotypes, increasing $\left[\mathrm{CO}_{2}\right]$ from 400 to $700 \mu \mathrm{mol} \mathrm{mol}^{-1}$ significantly increased $\mathrm{P}_{\mathrm{N}}$ but gs and $\mathrm{E}$ were reduced significantly. Based on these findings, it is concluded that increasing $\mathrm{P}_{\mathrm{N}}$ and decreasing gs and $\mathrm{E}$ at elevated $\left[\mathrm{CO}_{2}\right]$ substantially contributes to the significant increases in $W_{U E}$ Inst and $W U E_{I n t r}[30,46,74]$. Enhanced WUE $E_{\text {Intr }}$ at elevated $\left[\mathrm{CO}_{2}\right]$ is related to maintenance of higher plant water potential $(\Psi)$ through reduced gs and greater fine root production [43]. Reduced gs in elevated $\left[\mathrm{CO}_{2}\right]$ may alter plant responses to drought and improve WUE [75].

Irrespective of levels of $\left[\mathrm{CO}_{2}\right]$, increasing levels of PPFD from 100 to $400 \mu \mathrm{mol} \mathrm{m} \mathrm{m}^{-2} \mathrm{~s}^{-1}$ increased $\mathrm{WUE}_{\mathrm{Total}}$, but there were no changes in $\mathrm{WUE}_{\text {Inst }}$. Increasing PPFD from 100 to $400 \mu \mathrm{mol} \mathrm{m}{ }^{-2} \mathrm{~s}^{-1}$ slightly reduced $\mathrm{WUE}_{\text {Intr }}$ from an average of 0.22 to $0.19 \mu \mathrm{mol} \mathrm{CO}_{2}$ $\mathrm{mmol} \mathrm{H}_{2} \mathrm{O}^{-1}$. This is a reflection of increases of gs from average of 15.33 to $19.35 \mathrm{mmol}$ $\mathrm{H}_{2} \mathrm{O} \mathrm{m}^{-2} \mathrm{~s}^{-1}$ and moderate increases in $\mathrm{P}_{\mathrm{N}}$ from average of 2.67 to $3.41 \mu \mathrm{mol} \mathrm{m}^{-2} \mathrm{~s}^{-1}$. In other crops, it has been reported that relationships between $W_{U E} E_{\text {Total }}$ and $W U E_{I n s t}$ may be either positive or negative [76]. Increases or decreases in WUE traits with varying PPFD and $\left[\mathrm{CO}_{2}\right]$ are determined by increases or decreases of $\mathrm{P}_{\mathrm{N}}$, gs, and $\mathrm{E}[4,13,46]$. As occurrences of drought episodes are becoming more common in tropical cacao regions [77-79], selection of cacao genotypes with high WUE under increasing levels of $\left[\mathrm{CO}_{2}\right]$ would be beneficial in sustaining yield potential of cacao in current and future drought prone areas.

\subsection{Nutrient Use Efficiency Traits}

\subsubsection{Nutrient Concentrations and Uptake}

Cacao genotypes, irrespective of levels of $\left[\mathrm{CO}_{2}\right]$ and PPFD, showed significant differences in macro-micro nutrient concentrations (Table 3). Overall, LCT EEN 37A, compared to the other genotypes, had the highest concentrations of $\mathrm{P}, \mathrm{K}, \mathrm{Ca}, \mathrm{Cu}$ and Fe. The concentrations of $\mathrm{P}, \mathrm{Ca}, \mathrm{Mg}$ and $\mathrm{Mn}$ were slightly higher, but concentrations of other macro and micronutrients were comparable to the concentrations reported in the literature $[50,80,81]$. In all the genotypes tested, irrespective of PPFD, increasing $\left[\mathrm{CO}_{2}\right]$ from 400 to $700 \mu \mathrm{mol} \mathrm{mol}^{-1}$ significantly reduced macro-micro nutrient concentrations; however, the effect of increasing $\left[\mathrm{CO}_{2}\right]$ on $\mathrm{Zn}$ concentration was non-significant. This is a reflection of increased dry matter in the shoots (Table 1) of all cacao genotypes with increasing $\left[\mathrm{CO}_{2}\right]$ which created dilution effects on the nutrient concentrations. The decline in concentrations of all macro-micro nutrients in cacao genotypes with increasing levels of $\left[\mathrm{CO}_{2}\right]$ differed slightly from the conclusion drawn by Dong et al. [82] from meta-analysis of vegetable crops. They concluded that elevated $\left[\mathrm{CO}_{2}\right]$ enhanced yield in vegetable crops but decreased the concentration of nitrate, $\mathrm{Mg}, \mathrm{Fe}$, and $\mathrm{Zn}$ by 18.0, 9.2, 16.0 and 9.4\%, respectively, and increased the concentration of $\mathrm{Ca}$ by $8.2 \%$. However, the concentration of $\mathrm{P}, \mathrm{K}, \mathrm{S}, \mathrm{Cu}$ and $\mathrm{Mn}$ in that study were not affected by elevated $\left[\mathrm{CO}_{2}\right]$. In Amelonado cacao, 
Lahive et al. [46] reported that leaf $\mathrm{N}$ content decreased at elevated $\left[\mathrm{CO}_{2}\right]$. In mango leaves, elevated levels of $\left[\mathrm{CO}_{2}\right]$ reduced concentrations of several minerals [83]. With the exception of $\mathrm{N}, \mathrm{Cu}$ and $\mathrm{Mn}$, and irrespective of levels of [CO $\left.\mathrm{CO}_{2}\right]$, increasing PPFD from 100 to 400 $\mu \mathrm{mol} \mathrm{m} \mathrm{m}^{-2} \mathrm{~s}^{-1}$ reduced concentrations of the other macro and micronutrients. However, the effects were only significant for concentrations of $\mathrm{N}, \mathrm{K}, \mathrm{Ca}, \mathrm{Mg}$ and $\mathrm{Mn}$. In several tropical perennial cover crop legumes, increasing $\left[\mathrm{CO}_{2}\right]$ from 400 to $700 \mu \mathrm{mol} \mathrm{mol}{ }^{-1}$ slightly decreased all the macro-micro nutrient concentrations. However, increasing PPFD from 100 to $450 \mu \mathrm{mol} \mathrm{m}{ }^{-2} \mathrm{~s}^{-1}$ only slightly decreased concentrations of $\mathrm{K}, \mathrm{Ca}$ and Fe [62]. In another study with perennial legume cover crops, Baligar et al., [84] reported that increasing PPFD from 200 to $400 \mu \mathrm{mol} \mathrm{m}{ }^{-2} \mathrm{~s}^{-1}$ significantly decreased the concentrations of most of the micronutrients and they attributed this to increased dry matter at the slightly higher PPFD which caused dilution effects.

Uptake of all macro-micro nutrients were significantly influenced by genotypes and Amaz 15 had the highest nutrient uptake (Table 4). Overall, increasing levels of $\left[\mathrm{CO}_{2}\right]$ from 400 to $700 \mu \mathrm{mol} \mathrm{mol}{ }^{-1}$ and PPFD from 100 to $400 \mu \mathrm{mol} \mathrm{m}^{-2} \mathrm{~s}^{-1}$ significantly increased uptake of all the macro-micro nutrients. In cacao genotype comum, Baligar et al. [35] reported that increasing $\left[\mathrm{CO}_{2}\right]$ from 380 to $700 \mu \mathrm{mol} \mathrm{mol}^{-1}$ increased uptake of all essential nutrients and further stated that such an increase in nutrient uptake at higher $\left[\mathrm{CO}_{2}\right]$ is due to increased demand for mineral nutrients due to enhanced dry matter accumulation. The overall nutrient accumulation in the current study was in the order of $\mathrm{N}>\mathrm{Ca}>\mathrm{K}>\mathrm{Mg}>\mathrm{P}$ for macro nutrients and $\mathrm{Mn}>\mathrm{Zn}>\mathrm{Fe}>\mathrm{B}>\mathrm{Cu}$ for micronutrients.

\subsubsection{Nutrient Influx (IN) and Transport (TR)}

In most of the cacao growing regions, cacao is often grown in infertile acidic soils and is subjected to the high temperature and radiation common with low soil moisture levels. Such climatic stresses could have major effects on the ability of plants to influx (IN) nutrients from soil through the roots and to transport (TR) these essential nutrients to shoots. In addition to these stresses, increasing atmospheric concentrations of $\left[\mathrm{CO}_{2}\right]$ could aggravate rates of IN and TR by increasing transpiration losses and photosynthesis. However, very limited information is available on how increasing levels of $\left[\mathrm{CO}_{2}\right]$ and low to adequate levels of PPFD affect IN and TR of macro-micro nutrients in cacao. In the current study, IN for all macro and micro nutrients were significantly influenced by genotypes, $\left[\mathrm{CO}_{2}\right]$ and PPFD (Table 5). Irrespective of levels of $\left[\mathrm{CO}_{2}\right]$ and PPFD, cacao genotype SCA 6 had higher IN of all macro-micro nutrients. Based on these findings SCA 6 could be a superior genotype to use as rootstock in establishing new plantations in infertile soils under changing climatic conditions. In the current study, irrespective of levels of PPFD, IN for all macro-micro nutrients increased significantly by increasing $\left[\mathrm{CO}_{2}\right]$ from 400 to $700 \mu \mathrm{mol} \mathrm{mol}^{-1}$. It has been previously reported in cacao genotype comum that increasing $\left[\mathrm{CO}_{2}\right]$ from 380 to $700 \mu \mathrm{mol} \mathrm{mol}{ }^{-1}$ tended to increase IN for many of the essential nutrients [35]. In the current study, increasing PPFD from 100 to $400 \mu \mathrm{mol} \mathrm{m}^{-2} \mathrm{~s}^{-1}$ significantly increased IN for all nutrients irrespective of levels of $\left[\mathrm{CO}_{2}\right]$. Baligar et al. [35] found a similar result, but also that increases in PPFD to $1050 \mu \mathrm{mol} \mathrm{m}{ }^{-2} \mathrm{~s}^{-1}$ tended to decrease IN for $\mathrm{N}, \mathrm{K}, \mathrm{Ca}, \mathrm{Mg}, \mathrm{P}, \mathrm{S}, \mathrm{Cu}$ and Fe. Increased plant influx (IN) of more nutrients from the growth medium helps meet increased demand by increased shoot biomass accumulation.

With the exceptions of $\mathrm{K}, \mathrm{Ca}$ and $\mathrm{Cu}$, transport (TR) for the other macro-micro nutrients were significantly influenced by cacao genotypes (Table 6). SCA 6 was superior in transport of N, Ca, Fe, and Mn and Coca 3370 was superior in TR for Mg, B and Mn. Overall, with a few exceptions, TR for all the macro-micro nutrients were significantly increased by increasing $\left[\mathrm{CO}_{2}\right]$ from 400 to $700 \mu \mathrm{mol} \mathrm{mol}{ }^{-1}$ and PPFD from 100 to $400 \mu \mathrm{mol} \mathrm{m}^{-2} \mathrm{~s}^{-1}$. In cacao genotype comum, Baligar et al. [35] reported that increasing $\left[\mathrm{CO}_{2}\right]$ from 380 to 700 $\mu \mathrm{mol} \mathrm{mol}{ }^{-1}$ decreased TR of N, Ca, and Zn, and increased TR for other elements. Such variations in IN and TR at varying levels of $\left[\mathrm{CO}_{2}\right]$ and PPFD could be related to nature of genotypes and their interactions with levels of $\left[\mathrm{CO}_{2}\right]$ and PPFD. 
Table 3. The effect of $\left[\mathrm{CO}_{2}\right]$ and photosynthetic photon flux density (PPFD) on macro-micro nutrient concentrations of seven cacao genotypes.

\begin{tabular}{|c|c|c|c|c|c|c|c|c|c|c|c|}
\hline \multirow{2}{*}{$\begin{array}{c}\mathrm{CO}_{2} \\
(\mu \mathrm{mol} \\
\left.\mathrm{mol}^{-1}\right)\end{array}$} & \multirow{2}{*}{$\begin{array}{c}\text { PPFD } \\
(\mu \mathrm{mol} \\
\left.\mathrm{m}^{-2} \mathrm{~s}^{-1}\right)\end{array}$} & $\mathbf{N}$ & $\mathbf{P}$ & $\mathbf{K}$ & $\mathrm{Ca}$ & Mg & B & $\mathrm{Cu}$ & $\mathrm{Fe}$ & Mn & $\mathrm{Zn}$ \\
\hline & & \multicolumn{5}{|c|}{$\mathrm{mg} \mathrm{g}^{-1}$} & \multicolumn{5}{|c|}{$\mu g^{-1}$} \\
\hline & & \multicolumn{10}{|c|}{ Catongo } \\
\hline \multirow[t]{3}{*}{400} & 100 & 27.31 & 4.48 & 15.40 & 15.87 & 6.80 & 34.30 & 24.15 & 61.90 & 77.54 & 40.83 \\
\hline & 200 & 28.92 & 4.26 & 14.53 & 15.79 & 6.77 & 34.83 & 22.47 & 57.63 & 62.91 & 36.75 \\
\hline & 400 & 31.46 & 5.04 & 15.54 & 15.36 & 6.34 & 32.68 & 24.88 & 95.58 & 55.72 & 51.21 \\
\hline \multirow[t]{4}{*}{700} & 100 & 25.84 & 4.00 & 15.82 & 14.86 & 6.26 & 28.38 & 18.81 & 25.66 & 63.10 & 33.31 \\
\hline & 200 & 24.15 & 3.65 & 14.03 & 13.81 & 6.57 & 23.86 & 18.14 & 18.00 & 49.46 & 34.98 \\
\hline & 400 & 26.97 & 3.71 & 12.99 & 12.94 & 5.57 & 24.54 & 17.11 & 19.54 & 44.68 & 36.48 \\
\hline & & \multicolumn{10}{|c|}{ Coca 3370} \\
\hline \multirow[t]{3}{*}{400} & 100 & 27.00 & 3.82 & 14.70 & 14.82 & 8.04 & 30.76 & 21.11 & 56.73 & 110.06 & 58.68 \\
\hline & 200 & 25.46 & 4.02 & 15.02 & 15.13 & 8.35 & 33.51 & 19.90 & 54.62 & 73.60 & 40.85 \\
\hline & 400 & 28.15 & 3.91 & 12.83 & 14.09 & 7.50 & 29.28 & 21.21 & 72.55 & 63.10 & 41.48 \\
\hline \multirow[t]{4}{*}{700} & 100 & 26.21 & 4.15 & 12.92 & 13.95 & 7.03 & 24.20 & 17.39 & 18.73 & 67.50 & 41.66 \\
\hline & 200 & 25.15 & 4.45 & 13.22 & 13.71 & 7.89 & 24.32 & 18.87 & 21.72 & 61.34 & 48.28 \\
\hline & 400 & 24.54 & 3.85 & 11.23 & 11.84 & 6.20 & 19.32 & 17.27 & 34.04 & 36.67 & 46.01 \\
\hline & & \multicolumn{10}{|c|}{ CCN 51} \\
\hline \multirow[t]{3}{*}{400} & 100 & 28.85 & 4.33 & 13.64 & 14.35 & 6.39 & 30.29 & 23.14 & 60.94 & 74.38 & 54.68 \\
\hline & 200 & 27.68 & 4.47 & 14.82 & 15.64 & 7.24 & 30.77 & 22.56 & 44.73 & 66.95 & 47.11 \\
\hline & 400 & 29.71 & 4.20 & 14.94 & 14.03 & 6.25 & 27.05 & 25.80 & 52.43 & 43.86 & 41.47 \\
\hline \multirow[t]{4}{*}{700} & 100 & 24.94 & 4.33 & 13.93 & 16.48 & 6.80 & 24.94 & 21.98 & 21.77 & 79.65 & 76.98 \\
\hline & 200 & 24.69 & 3.63 & 12.80 & 13.89 & 6.53 & 20.53 & 17.58 & 26.86 & 54.54 & 50.82 \\
\hline & 400 & 24.91 & 3.73 & 11.48 & 13.56 & 6.34 & 23.82 & 19.11 & 40.12 & 47.74 & 54.03 \\
\hline & & \multicolumn{10}{|c|}{ Amaz 15} \\
\hline \multirow[t]{3}{*}{400} & 100 & 24.83 & 4.15 & 13.49 & 13.62 & 6.94 & 26.66 & 17.35 & 45.41 & 68.37 & 46.03 \\
\hline & 200 & 25.17 & 4.28 & 14.45 & 15.57 & 7.82 & 31.27 & 19.75 & 43.78 & 61.22 & 49.74 \\
\hline & 400 & 25.52 & 3.69 & 11.92 & 13.70 & 6.73 & 29.14 & 19.65 & 31.74 & 47.84 & 71.18 \\
\hline \multirow[t]{4}{*}{700} & 100 & 23.31 & 4.14 & 13.19 & 14.26 & 7.55 & 23.56 & 16.61 & 14.38 & 68.17 & 45.67 \\
\hline & 200 & 22.02 & 3.77 & 11.29 & 12.04 & 6.74 & 19.07 & 14.54 & 20.07 & 47.75 & 43.13 \\
\hline & 400 & 21.73 & 3.48 & 10.22 & 11.24 & 5.98 & 19.44 & 14.73 & 15.46 & 47.13 & 40.99 \\
\hline & & & & & & LCT & 37A & & & & \\
\hline 400 & 100 & 26.70 & 4.57 & 17.73 & 16.84 & 6.76 & 30.61 & 24.52 & 77.09 & 74.45 & 57.56 \\
\hline & 200 & 30.72 & 5.13 & 16.91 & 16.16 & 7.83 & 32.85 & 41.88 & 108.84 & 59.46 & 58.52 \\
\hline & 400 & 32.58 & 4.75 & 15.98 & 15.25 & 7.43 & 31.79 & 36.45 & 80.44 & 45.79 & 45.27 \\
\hline 700 & 100 & 22.39 & 4.06 & 14.27 & 13.66 & 6.41 & 22.39 & 16.83 & 30.97 & 56.90 & 47.76 \\
\hline & 200 & 24.37 & 3.57 & 13.58 & 13.46 & 5.79 & 20.62 & 15.62 & 36.18 & 54.53 & 48.44 \\
\hline & 400 & 23.39 & 4.14 & 11.46 & 14.54 & 6.62 & 20.47 & 17.68 & 46.68 & 42.68 & 45.84 \\
\hline & & & & & & $\mathrm{Na} 33$ & & & & & \\
\hline 400 & 100 & 23.11 & 3.81 & 13.79 & 15.87 & 6.16 & 31.05 & 20.51 & 67.26 & 85.89 & 66.47 \\
\hline & 200 & 26.13 & 3.95 & 13.28 & 17.77 & 6.62 & 34.37 & 22.94 & 83.68 & 64.51 & 61.70 \\
\hline & 400 & 28.70 & 3.68 & 14.51 & 14.48 & 6.08 & 34.70 & 21.31 & 87.95 & 46.13 & 60.22 \\
\hline 700 & 100 & 23.84 & 3.71 & 15.05 & 16.80 & 6.50 & 30.02 & 18.35 & 53.72 & 63.89 & 51.03 \\
\hline & 200 & 22.35 & 3.59 & 11.19 & 14.74 & 5.87 & 17.49 & 17.79 & 44.94 & 51.63 & 49.01 \\
\hline & 400 & 20.85 & 3.58 & 10.47 & 12.87 & 5.76 & 21.79 & 17.81 & 47.56 & 39.90 & 63.92 \\
\hline & & & & & & SCA 6 & & & & & \\
\hline 400 & 100 & 24.71 & 3.40 & 13.51 & 13.69 & 6.28 & 29.44 & 16.05 & 57.65 & 75.17 & 44.33 \\
\hline & 200 & 25.53 & 3.40 & 14.04 & 15.53 & 6.93 & 31.24 & 19.76 & 82.19 & 69.80 & 62.89 \\
\hline & 400 & 28.23 & 3.65 & 13.02 & 13.91 & 6.53 & 33.44 & 23.59 & 95.41 & 62.92 & 43.49 \\
\hline 700 & 100 & 22.08 & 3.30 & 13.55 & 14.41 & 6.33 & 22.29 & 15.78 & 32.26 & 67.81 & 46.56 \\
\hline & 200 & 22.21 & 2.92 & 10.22 & 11.88 & 5.46 & 18.79 & 14.00 & 34.43 & 50.48 & 36.46 \\
\hline & 400 & 23.31 & 3.60 & 11.44 & 13.36 & 6.19 & 23.67 & 17.57 & 50.73 & 45.28 & 55.06 \\
\hline & & & & & Sig $_{1}$ & nce & & & & & \\
\hline Geno & pe $(G)$ & $* *$ & $* *$ & $* *$ & $* *$ & $* *$ & * & $* *$ & $* *$ & $*$ & $* *$ \\
\hline [CC & (C) & $* *$ & $* *$ & $* *$ & $* *$ & $* *$ & $* *$ & $* *$ & $* *$ & $* *$ & NS \\
\hline $\mathrm{PP}$ & $(\mathrm{P})$ & $*$ & NS & $* *$ & $* *$ & $*$ & NS & NS & NS & $* *$ & NS \\
\hline
\end{tabular}

$*, * *$ Significant at 0.05 and 0.01 levels of probability, respectively. NS = Not significant. 
Table 4. The effect of $\left[\mathrm{CO}_{2}\right]$ and photosynthetic photon flux density (PPFD) on macro-micro nutrient uptake of seven cacao genotypes.

\begin{tabular}{|c|c|c|c|c|c|c|c|c|c|c|c|}
\hline \multirow{2}{*}{$\begin{array}{c}\mathrm{CO}_{2} \\
(\mu \mathrm{mol} \\
\left.\mathrm{mol}^{-1}\right)\end{array}$} & \multirow{2}{*}{$\begin{array}{c}\text { PPFD } \\
(\mu \mathrm{mol} \\
\left.\mathrm{m}^{-2} \mathrm{~s}^{-1}\right)\end{array}$} & $\mathbf{N}$ & $\mathbf{P}$ & $\mathbf{K}$ & $\mathrm{Ca}$ & $\mathrm{Mg}$ & B & $\mathrm{Cu}$ & $\mathrm{Fe}$ & Mn & $\mathrm{Zn}$ \\
\hline & & \multicolumn{5}{|c|}{$\mathrm{mg} /$ plant } & \multicolumn{5}{|c|}{$\mu \mathrm{g} /$ plant } \\
\hline & & \multicolumn{10}{|c|}{ Catongo } \\
\hline \multirow[t]{3}{*}{400} & 100 & 181.9 & 29.68 & 101.9 & 105.4 & 45.18 & 229.1 & 161.1 & 417.9 & 513.7 & 273.3 \\
\hline & 200 & 193.7 & 28.33 & 98.1 & 106.0 & 45.69 & 235.3 & 150.1 & 380.1 & 416.4 & 252.7 \\
\hline & 400 & 178.4 & 28.59 & 88.0 & 87.1 & 35.96 & 185.3 & 140.9 & 541.6 & 315.6 & 290.3 \\
\hline \multirow[t]{4}{*}{700} & 100 & 273.8 & 42.21 & 167.2 & 157.5 & 66.29 & 299.2 & 198.9 & 287.3 & 664.8 & 354.4 \\
\hline & 200 & 305.3 & 45.46 & 169.9 & 169.9 & 81.61 & 301.8 & 222.3 & 215.9 & 608.9 & 456.2 \\
\hline & 400 & 317.7 & 43.79 & 152.9 & 153.4 & 66.65 & 295.7 & 203.5 & 243.8 & 523.8 & 446.5 \\
\hline & & \multicolumn{10}{|c|}{ Coca 3370} \\
\hline \multirow[t]{3}{*}{400} & 100 & 168.6 & 23.64 & 91.5 & 92.8 & 50.79 & 193.5 & 133.2 & 365.3 & 695.8 & 363.9 \\
\hline & 200 & 236.4 & 37.28 & 140.2 & 140.5 & 77.85 & 311.6 & 184.8 & 499.3 & 683.4 & 379.0 \\
\hline & 400 & 326.9 & 45.56 & 148.2 & 164.7 & 87.26 & 337.9 & 245.5 & 855.8 & 738.7 & 484.3 \\
\hline \multirow[t]{4}{*}{700} & 100 & 290.4 & 46.02 & 143.8 & 153.7 & 77.97 & 268.9 & 192.3 & 195.4 & 759.5 & 462.4 \\
\hline & 200 & 427.6 & 74.69 & 223.3 & 229.9 & 134.66 & 411.3 & 318.5 & 419.4 & 1055.5 & 840.9 \\
\hline & 400 & 447.9 & 70.49 & 208.1 & 214.7 & 115.23 & 353.7 & 323.4 & 607.4 & 675.6 & 889.6 \\
\hline & & \multicolumn{10}{|c|}{ CCN 51} \\
\hline \multirow[t]{3}{*}{400} & 100 & 137.8 & 20.65 & 64.2 & 69.0 & 30.70 & 150.6 & 115.1 & 322.4 & 349.0 & 257.9 \\
\hline & 200 & 196.8 & 31.84 & 105.0 & 111.4 & 51.50 & 217.9 & 161.0 & 320.8 & 475.9 & 334.3 \\
\hline & 400 & 238.3 & 33.56 & 121.7 & 111.7 & 50.47 & 217.1 & 202.1 & 390.3 & 343.9 & 331.2 \\
\hline \multirow[t]{4}{*}{700} & 100 & 295.5 & 51.38 & 166.1 & 197.0 & 81.72 & 295.0 & 262.4 & 262.6 & 929.6 & 874.9 \\
\hline & 200 & 360.7 & 52.37 & 185.6 & 200.9 & 95.23 & 299.6 & 257.3 & 401.6 & 803.5 & 734.4 \\
\hline & 400 & 521.5 & 79.71 & 240.4 & 285.4 & 136.42 & 515.1 & 405.8 & 888.1 & 1036.3 & 1150.2 \\
\hline & & \multicolumn{10}{|c|}{ Amaz 15} \\
\hline \multirow[t]{3}{*}{400} & 100 & 184.5 & 30.67 & 100.1 & 100.9 & 51.36 & 195.8 & 128.5 & 342.4 & 504.5 & 342.4 \\
\hline & 200 & 254.8 & 42.82 & 143.8 & 157.2 & 78.54 & 311.4 & 195.6 & 446.2 & 614.6 & 502.8 \\
\hline & 400 & 234.8 & 34.19 & 109.6 & 126.6 & 62.87 & 243.6 & 179.8 & 320.3 & 444.5 & 705.7 \\
\hline \multirow[t]{4}{*}{700} & 100 & 399.3 & 71.40 & 226.4 & 245.4 & 130.08 & 406.2 & 286.9 & 247.0 & 1174.0 & 785.6 \\
\hline & 200 & 459.9 & 79.81 & 234.8 & 252.1 & 142.20 & 404.9 & 304.8 & 418.9 & 998.8 & 880.4 \\
\hline & 400 & 509.1 & 81.96 & 239.9 & 264.1 & 140.27 & 454.1 & 344.7 & 366.8 & 1111.3 & 983.2 \\
\hline & & & & & & LCT & $37 \mathrm{~A}$ & & & & \\
\hline 400 & 100 & 82.1 & 13.38 & 51.5 & 51.2 & 20.41 & 90.4 & 69.5 & 216.3 & 231.3 & 162.5 \\
\hline & 200 & 137.7 & 23.46 & 76.2 & 71.5 & 34.44 & 144.9 & 193.9 & 491.6 & 249.9 & 264.4 \\
\hline & 400 & 118.9 & 18.20 & 60.2 & 56.7 & 26.58 & 123.8 & 121.0 & 276.5 & 186.0 & 173.9 \\
\hline 700 & 100 & 311.9 & 56.55 & 198.8 & 189.9 & 89.18 & 310.3 & 233.7 & 429.1 & 792.1 & 664.2 \\
\hline & 200 & 346.0 & 50.47 & 188.8 & 189.2 & 82.05 & 288.0 & 223.7 & 524.1 & 767.6 & 684.7 \\
\hline & 400 & 387.4 & 68.72 & 189.4 & 239.2 & 110.06 & 337.8 & 287.8 & 743.6 & 703.7 & 777.9 \\
\hline & & & & & & $\mathrm{Na} 33$ & & & & & \\
\hline 400 & 100 & 149.2 & 24.50 & 88.9 & 102.3 & 40.04 & 202.4 & 132.8 & 410.2 & 576.1 & 424.9 \\
\hline & 200 & 213.5 & 32.14 & 108.9 & 146.0 & 54.84 & 282.9 & 183.9 & 650.1 & 541.4 & 495.1 \\
\hline & 400 & 140.9 & 18.42 & 73.6 & 72.3 & 30.73 & 172.5 & 103.5 & 361.6 & 229.7 & 293.7 \\
\hline 700 & 100 & 193.6 & 29.74 & 120.4 & 135.2 & 52.68 & 241.4 & 147.2 & 425.7 & 524.4 & 411.3 \\
\hline & 200 & 411.1 & 66.21 & 207.1 & 269.6 & 109.15 & 326.9 & 321.6 & 773.0 & 974.4 & 920.9 \\
\hline & 400 & 443.2 & 76.07 & 222.4 & 272.1 & 122.75 & 462.6 & 375.5 & 1005.5 & 842.9 & 1436.6 \\
\hline & & & & & & SCA 6 & & & & & \\
\hline 400 & 100 & 149.2 & 20.43 & 81.69 & 82.63 & 37.87 & 177.2 & 96.8 & 348.3 & 454.9 & 266.6 \\
\hline & 200 & 151.2 & 20.28 & 83.63 & 93.33 & 41.69 & 190.1 & 118.1 & 496.9 & 423.0 & 366.7 \\
\hline & 400 & 232.6 & 30.07 & 108.20 & 114.97 & 54.32 & 280.7 & 188.7 & 707.4 & 515.0 & 355.8 \\
\hline 700 & 100 & 279.7 & 41.96 & 171.99 & 183.14 & 80.41 & 282.5 & 201.2 & 407.8 & 864.1 & 593.8 \\
\hline & 200 & 352.3 & 45.76 & 162.28 & 187.20 & 86.23 & 296.9 & 221.0 & 556.5 & 799.7 & 582.1 \\
\hline & 400 & 453.2 & 70.70 & 224.24 & 261.73 & 122.61 & 465.4 & 342.1 & 1017.3 & 916.0 & 1091.9 \\
\hline & & & & & Sigr & ance & & & & & \\
\hline Geno & pe $(G)$ & $* *$ & $* *$ & $* *$ & $* *$ & $* *$ & $* *$ & $* *$ & $* *$ & ** & $* *$ \\
\hline [CC & $(\mathrm{C})$ & $* *$ & $* *$ & $* *$ & $* *$ & $* *$ & $* *$ & $* *$ & NS & $* *$ & $* *$ \\
\hline $\mathrm{PP}$ & $(\mathrm{P})$ & $* *$ & $* *$ & $* *$ & $* *$ & $* *$ & $* *$ & $* *$ & $* *$ & NS & $* *$ \\
\hline
\end{tabular}

*** Significant at 0.05 and 0.01 levels of probability, respectively. NS $=$ Not significant. 
Table 5. The effect of $\left[\mathrm{CO}_{2}\right]$ and photosynthetic photon flux density (PPFD) on macro-micro influx by root length of seven cacao genotypes.

\begin{tabular}{|c|c|c|c|c|c|c|c|c|c|c|c|}
\hline \multirow{2}{*}{$\begin{array}{c}\mathrm{CO}_{2} \\
(\mu \mathrm{mol} \\
\left.\mathrm{mol}^{-1}\right)\end{array}$} & \multirow{2}{*}{$\begin{array}{c}\text { PPFD } \\
(\mu \mathrm{mol} \\
\left.\mathrm{m}^{-2} \mathrm{~s}^{-1}\right)\end{array}$} & $\mathbf{N}$ & $\mathbf{P}$ & $\mathbf{K}$ & $\mathrm{Ca}$ & Mg & B & $\mathrm{Cu}$ & $\mathrm{Fe}$ & Mn & Zn \\
\hline & & \multicolumn{5}{|c|}{ pmol cm $\operatorname{root}^{-1} \mathrm{~s}^{-1}$} & \multicolumn{5}{|c|}{ pmol cm $\operatorname{root}^{-1} \mathrm{~s}^{-1}\left(\times 10^{-3}\right)$} \\
\hline & & \multicolumn{10}{|c|}{ Catongo } \\
\hline \multirow[t]{3}{*}{400} & 100 & 0.98 & 0.07 & 0.19 & 0.21 & 0.14 & 1.62 & 0.19 & 0.61 & 0.73 & 0.31 \\
\hline & 200 & 1.04 & 0.07 & 0.18 & 0.21 & 0.14 & 1.64 & 0.18 & 0.54 & 0.58 & 0.27 \\
\hline & 400 & 1.00 & 0.07 & 0.17 & 0.18 & 0.12 & 1.36 & 0.18 & 0.82 & 0.46 & 0.34 \\
\hline \multirow[t]{4}{*}{700} & 100 & 1.53 & 0.10 & 0.34 & 0.32 & 0.22 & 2.19 & 0.25 & 0.42 & 0.97 & 0.41 \\
\hline & 200 & 1.58 & 0.10 & 0.32 & 0.32 & 0.25 & 2.03 & 0.26 & 0.30 & 0.83 & 0.49 \\
\hline & 400 & 1.69 & 0.10 & 0.29 & 0.29 & 0.20 & 2.03 & 0.24 & 0.33 & 0.72 & 0.49 \\
\hline & & \multicolumn{10}{|c|}{ Coca 3370} \\
\hline \multirow[t]{3}{*}{400} & 100 & 1.19 & 0.07 & 0.23 & 0.24 & 0.21 & 1.84 & 0.22 & 0.69 & 1.33 & 0.56 \\
\hline & 200 & 1.26 & 0.09 & 0.27 & 0.27 & 0.24 & 2.21 & 0.22 & 0.71 & 0.96 & 0.43 \\
\hline & 400 & 1.80 & 0.11 & 0.29 & 0.32 & 0.28 & 2.45 & 0.30 & 1.20 & 1.05 & 0.56 \\
\hline \multirow[t]{4}{*}{700} & 100 & 1.62 & 0.11 & 0.29 & 0.31 & 0.25 & 1.99 & 0.24 & 0.29 & 1.11 & 0.55 \\
\hline & 200 & 2.12 & 0.17 & 0.39 & 0.41 & 0.39 & 2.66 & 0.35 & 0.51 & 1.35 & 0.87 \\
\hline & 400 & 2.29 & 0.16 & 0.37 & 0.39 & 0.34 & 2.35 & 0.36 & 0.82 & 0.89 & 0.93 \\
\hline & & \multicolumn{10}{|c|}{ CCN 51} \\
\hline \multirow[t]{3}{*}{400} & 100 & 1.07 & 0.07 & 0.17 & 0.21 & 0.14 & 1.53 & 0.19 & 0.76 & 0.77 & 0.42 \\
\hline & 200 & 1.37 & 0.09 & 0.26 & 0.28 & 0.21 & 1.99 & 0.24 & 0.58 & 0.89 & 0.49 \\
\hline & 400 & 1.69 & 0.10 & 0.30 & 0.29 & 0.21 & 1.99 & 0.31 & 0.77 & 0.65 & 0.49 \\
\hline \multirow[t]{4}{*}{700} & 100 & 1.63 & 0.13 & 0.33 & 0.39 & 0.26 & 2.12 & 0.31 & 0.37 & 1.35 & 1.06 \\
\hline & 200 & 1.89 & 0.12 & 0.35 & 0.38 & 0.29 & 2.04 & 0.29 & 0.53 & 1.09 & 0.82 \\
\hline & 400 & 2.31 & 0.16 & 0.38 & 0.45 & 0.35 & 2.94 & 0.39 & 1.00 & 1.17 & 1.09 \\
\hline & & \multicolumn{10}{|c|}{ Amaz 15} \\
\hline \multirow[t]{3}{*}{400} & 100 & 1.24 & 0.09 & 0.24 & 0.25 & 0.20 & 1.75 & 0.19 & 0.61 & 0.91 & 0.49 \\
\hline & 200 & 1.38 & 0.11 & 0.28 & 0.31 & 0.25 & 2.25 & 0.24 & 0.63 & 0.88 & 0.59 \\
\hline & 400 & 1.39 & 0.09 & 0.23 & 0.27 & 0.22 & 1.99 & 0.24 & 0.48 & 0.70 & 0.89 \\
\hline \multirow[t]{4}{*}{700} & 100 & 1.89 & 0.15 & 0.38 & 0.41 & 0.36 & 2.47 & 0.30 & 0.30 & 1.45 & 0.81 \\
\hline & 200 & 2.13 & 0.16 & 0.39 & 0.42 & 0.38 & 2.41 & 0.31 & 0.50 & 1.20 & 0.89 \\
\hline & 400 & 2.22 & 0.16 & 0.37 & 0.41 & 0.36 & 2.58 & 0.33 & 0.41 & 1.25 & 0.92 \\
\hline & & & & & & LCT & $37 \mathrm{~A}$ & & & & \\
\hline 400 & 100 & 0.68 & 0.05 & 0.16 & 0.17 & 0.11 & 1.06 & 0.14 & 0.54 & 0.54 & 0.30 \\
\hline & 200 & 1.13 & 0.08 & 0.22 & 0.22 & 0.17 & 1.61 & 0.36 & 1.11 & 0.56 & 0.46 \\
\hline & 400 & 0.95 & 0.06 & 0.17 & 0.17 & 0.13 & 1.30 & 0.23 & 0.64 & 0.38 & 0.28 \\
\hline 700 & 100 & 1.69 & 0.14 & 0.39 & 0.37 & 0.28 & 2.25 & 0.28 & 0.61 & 1.12 & 0.78 \\
\hline & 200 & 1.89 & 0.12 & 0.37 & 0.37 & 0.26 & 2.07 & 0.26 & 0.74 & 1.09 & 0.81 \\
\hline & 400 & 1.89 & 0.15 & 0.33 & 0.42 & 0.31 & 2.17 & 0.31 & 0.96 & 0.89 & 0.80 \\
\hline & & & & & & $\mathrm{Na} 33$ & & & & & \\
\hline 400 & 100 & 0.97 & 0.07 & 0.21 & 0.25 & 0.15 & 1.74 & 0.19 & 0.75 & 0.99 & 0.61 \\
\hline & 200 & 1.29 & 0.09 & 0.23 & 0.32 & 0.19 & 2.24 & 0.25 & 1.08 & 0.84 & 0.65 \\
\hline & 400 & 1.05 & 0.06 & 0.19 & 0.19 & 0.13 & 1.71 & 0.16 & 0.83 & 0.45 & 0.47 \\
\hline 700 & 100 & 1.48 & 0.10 & 0.33 & 0.38 & 0.24 & 2.44 & 0.24 & 0.85 & 1.05 & 0.68 \\
\hline & 200 & 1.88 & 0.14 & 0.34 & 0.44 & 0.29 & 1.93 & 0.32 & 0.91 & 1.15 & 0.89 \\
\hline & 400 & 1.89 & 0.15 & 0.34 & 0.41 & 0.31 & 2.59 & 0.35 & 1.12 & 0.94 & 1.25 \\
\hline & & & & & & SCA 6 & & & & & \\
\hline 400 & 100 & 1.37 & 0.08 & 0.27 & 0.28 & 0.21 & 2.16 & 0.20 & 0.86 & 1.11 & 0.51 \\
\hline & 200 & 1.34 & 0.08 & 0.26 & 0.31 & 0.22 & 2.21 & 0.24 & 1.16 & 1.00 & 0.68 \\
\hline & 400 & 1.71 & 0.09 & 0.28 & 0.31 & 0.23 & 2.71 & 0.31 & 1.35 & 0.99 & 0.54 \\
\hline 700 & 100 & 1.95 & 0.13 & 0.43 & 0.45 & 0.32 & 2.56 & 0.31 & 0.74 & 1.54 & 0.85 \\
\hline & 200 & 2.50 & 0.14 & 0.41 & 0.47 & 0.35 & 2.72 & 0.34 & 1.02 & 1.46 & 0.87 \\
\hline & 400 & 2.48 & 0.17 & 0.44 & 0.51 & 0.38 & 3.37 & 0.41 & 1.43 & 1.28 & 1.28 \\
\hline & & & & & Sig & nce & & & & & \\
\hline Geno & pe $(G)$ & $* *$ & $* *$ & $* *$ & $* *$ & $* *$ & $* *$ & $* *$ & $* *$ & $* *$ & $* *$ \\
\hline [CC & & $* *$ & $* *$ & $* *$ & $* *$ & $* *$ & $* *$ & $* *$ & NS & $* *$ & $* *$ \\
\hline $\mathrm{PP}$ & $(\mathrm{P})$ & $* *$ & $* *$ & NS & $* *$ & $* *$ & $*$ & $* *$ & $*$ & $* *$ & $*$ \\
\hline
\end{tabular}

*** Significant at 0.05 and 0.01 levels of probability, respectively. NS = Not significant. 
Table 6. The effect of $\left[\mathrm{CO}_{2}\right]$ and photosynthetic photon flux density (PPFD) on macro-micro nutrient transport of seven cacao genotypes.

\begin{tabular}{|c|c|c|c|c|c|c|c|c|c|c|c|}
\hline \multirow{2}{*}{$\begin{array}{c}\mathrm{CO}_{2} \\
(\mu \mathrm{mol} \\
\left.\mathrm{mol}^{-1}\right)\end{array}$} & \multirow{2}{*}{$\begin{array}{c}\text { PPFD } \\
(\mu \mathrm{mol} \\
\left.\mathrm{m}^{-2} \mathrm{~s}^{-1}\right)\end{array}$} & $\mathbf{N}$ & $\mathbf{P}$ & $\mathbf{K}$ & $\mathrm{Ca}$ & Mg & B & $\mathrm{Cu}$ & $\mathrm{Fe}$ & Mn & $\mathrm{Zn}$ \\
\hline & & \multicolumn{10}{|c|}{ pmol g shoot $^{-1} \mathrm{~s}^{-1}$} \\
\hline & & \multicolumn{10}{|c|}{ Catongo } \\
\hline \multirow[t]{3}{*}{400} & 100 & 699.9 & 50.39 & 138.7 & 150.1 & 102.3 & 1.16 & 0.14 & 0.43 & 0.53 & 0.22 \\
\hline & 200 & 743.1 & 47.54 & 130.4 & 149.3 & 101.9 & 1.17 & 0.13 & 0.39 & 0.42 & 0.19 \\
\hline & 400 & 768.4 & 53.95 & 131.6 & 138.1 & 89.7 & 1.04 & 0.13 & 0.63 & 0.35 & 0.26 \\
\hline \multirow[t]{4}{*}{700} & 100 & 826.2 & 56.80 & 180.9 & 170.9 & 116.6 & 1.18 & 0.13 & 0.22 & 0.52 & 0.22 \\
\hline & 200 & 803.2 & 53.77 & 165.1 & 163.9 & 127.1 & 1.03 & 0.13 & 0.15 & 0.42 & 0.25 \\
\hline & 400 & 879.2 & 53.47 & 149.9 & 151.3 & 105.5 & 1.04 & 0.12 & 0.17 & 0.37 & 0.25 \\
\hline & & \multicolumn{10}{|c|}{ Coca 3370} \\
\hline \multirow[t]{3}{*}{400} & 100 & 681.6 & 41.64 & 131.5 & 138.6 & 121.0 & 1.04 & 0.12 & 0.39 & 0.75 & 0.32 \\
\hline & 200 & 738.5 & 51.64 & 156.0 & 159.7 & 143.1 & 1.29 & 0.13 & 0.42 & 0.56 & 0.25 \\
\hline & 400 & 879.2 & 54.02 & 141.3 & 158.3 & 136.6 & 1.19 & 0.15 & 0.59 & 0.51 & 0.27 \\
\hline \multirow[t]{4}{*}{700} & 100 & 751.5 & 53.14 & 131.9 & 146.1 & 118.2 & 0.91 & 0.11 & 0.14 & 0.51 & 0.25 \\
\hline & 200 & 811.1 & 64.40 & 152.0 & 158.9 & 149.1 & 1.03 & 0.13 & 0.19 & 0.52 & 0.33 \\
\hline & 400 & 810.3 & 57.00 & 132.3 & 140.4 & 119.7 & 0.83 & 0.13 & 0.29 & 0.31 & 0.33 \\
\hline & & \multicolumn{10}{|c|}{ CCN 51} \\
\hline \multirow[t]{3}{*}{400} & 100 & 633.6 & 39.88 & 101.4 & 121.1 & 84.2 & 0.88 & 0.11 & 0.39 & 0.45 & 0.25 \\
\hline & 200 & 742.5 & 52.45 & 139.9 & 155.2 & 115.2 & 1.07 & 0.13 & 0.32 & 0.48 & 0.26 \\
\hline & 400 & 831.8 & 51.00 & 147.8 & 142.9 & 102.5 & 0.97 & 0.15 & 0.38 & 0.32 & 0.24 \\
\hline \multirow[t]{4}{*}{700} & 100 & 785.9 & 61.00 & 157.4 & 188.7 & 126.0 & 1.02 & 0.15 & 0.18 & 0.66 & 0.52 \\
\hline & 200 & 822.1 & 53.56 & 151.8 & 166.1 & 127.0 & 0.88 & 0.13 & 0.23 & 0.47 & 0.36 \\
\hline & 400 & 915.3 & 61.56 & 150.2 & 177.8 & 136.2 & 1.14 & 0.15 & 0.38 & 0.45 & 0.43 \\
\hline & & \multicolumn{10}{|c|}{ Amaz 15} \\
\hline \multirow[t]{3}{*}{400} & 100 & 684.5 & 51.47 & 134.6 & 138.2 & 113.5 & 0.97 & 0.11 & 0.33 & 0.51 & 0.27 \\
\hline & 200 & 767.8 & 58.74 & 158.7 & 172.5 & 140.5 & 1.26 & 0.13 & 0.35 & 0.49 & 0.33 \\
\hline & 400 & 726.7 & 46.86 & 121.6 & 143.3 & 113.9 & 1.07 & 0.13 & 0.25 & 0.36 & 0.46 \\
\hline \multirow[t]{4}{*}{700} & 100 & 804.0 & 64.18 & 163.2 & 176.4 & 152.7 & 1.06 & 0.13 & 0.13 & 0.61 & 0.34 \\
\hline & 200 & 797.4 & 61.40 & 145.9 & 155.6 & 142.8 & 0.90 & 0.12 & 0.19 & 0.45 & 0.33 \\
\hline & 400 & 812.0 & 58.31 & 136.2 & 149.5 & 129.9 & 0.94 & 0.12 & 0.15 & 0.46 & 0.33 \\
\hline & & \multicolumn{10}{|c|}{ LCT EEN 37A } \\
\hline 400 & 100 & 490.2 & 35.11 & 118.7 & 124.9 & 77.0 & 0.78 & 0.10 & 0.41 & 0.39 & 0.22 \\
\hline & 200 & 709.6 & 52.33 & 140.6 & 139.7 & 107.9 & 1.01 & 0.23 & 0.69 & 0.36 & 0.29 \\
\hline & 400 & 662.5 & 41.56 & 116.6 & 119.5 & 90.2 & 0.89 & 0.16 & 0.44 & 0.25 & 0.19 \\
\hline 700 & 100 & 766.7 & 62.42 & 175.8 & 168.4 & 128.8 & 1.01 & 0.13 & 0.27 & 0.51 & 0.35 \\
\hline & 200 & 835.5 & 54.32 & 165.6 & 165.3 & 115.8 & 0.92 & 0.12 & 0.32 & 0.48 & 0.36 \\
\hline & 400 & 838.2 & 66.65 & 146.2 & 186.3 & 138.9 & 0.96 & 0.14 & 0.43 & 0.39 & 0.35 \\
\hline & & & & & & $\mathrm{Na} 33$ & & & & & \\
\hline 400 & 100 & 573.3 & 41.70 & 121.1 & 146.7 & 90.7 & 1.03 & 0.11 & 0.44 & 0.58 & 0.36 \\
\hline & 200 & 710.4 & 47.35 & 126.9 & 176.8 & 105.8 & 1.24 & 0.14 & 0.59 & 0.46 & 0.36 \\
\hline & 400 & 640.1 & 35.01 & 113.5 & 120.4 & 79.8 & 1.04 & 0.10 & 0.50 & 0.27 & 0.28 \\
\hline 700 & 100 & 699.8 & 48.00 & 158.0 & 178.5 & 112.3 & 1.16 & 0.12 & 0.41 & 0.49 & 0.32 \\
\hline & 200 & 824.9 & 59.38 & 147.3 & 193.2 & 126.3 & 0.84 & 0.14 & 0.42 & 0.49 & 0.39 \\
\hline & 400 & 798.3 & 61.61 & 142.8 & 174.5 & 128.3 & 1.09 & 0.15 & 0.46 & 0.39 & 0.53 \\
\hline & & & & & & SCA 6 & & & & & \\
\hline 400 & 100 & 685.0 & 40.64 & 133.0 & 139.4 & 102.5 & 1.08 & 0.10 & 0.42 & 0.55 & 0.25 \\
\hline & 200 & 702.6 & 40.37 & 137.5 & 157.9 & 113.1 & 1.14 & 0.12 & 0.61 & 0.51 & 0.37 \\
\hline & 400 & 869.7 & 49.20 & 141.9 & 154.5 & 117.4 & 1.36 & 0.16 & 0.75 & 0.50 & 0.28 \\
\hline 700 & 100 & 786.6 & 52.28 & 172.2 & 183.2 & 131.1 & 1.03 & 0.12 & 0.29 & 0.63 & 0.35 \\
\hline & 200 & 837.1 & 48.70 & 136.3 & 158.5 & 119.0 & 0.91 & 0.12 & 0.33 & 0.49 & 0.29 \\
\hline & 400 & 921.4 & 63.86 & 161.0 & 186.9 & 142.1 & 1.22 & 0.15 & 0.51 & 0.46 & 0.47 \\
\hline & & & & & Sig & ance & & & & & \\
\hline Geno & pe $(G)$ & $* *$ & $*$ & NS & NS & $* *$ & * & NS & $* *$ & $* *$ & $* *$ \\
\hline [CC & (C) & $* *$ & $* *$ & $* *$ & $* *$ & $* *$ & $*$ & NS & $* *$ & NS & $* *$ \\
\hline $\mathrm{PP}$ & $(\mathrm{P})$ & $* *$ & $*$ & $*$ & $*$ & $* *$ & NS & $* *$ & NS & $* *$ & NS \\
\hline
\end{tabular}

*** Significant at 0.05 and 0.01 levels of probability, respectively. NS = Not significant. 


\subsubsection{Nutrient Use Efficiency}

With the exception of Mn, all cacao genotypes in this study, irrespective of levels of $\left[\mathrm{CO}_{2}\right]$ and PPFD, showed significant differences for NUE of all the other essential nutrients (Table 7). The existence of interspecific variations in NUE of macro and micro nutrients have been well documented for field, horticultural and perennial legume crops [62,63,85-88]. Variations in the growth and uptake and nutrient use efficiency among crop cultivars have been related to absorption, translocation, shoot demand, and dry matter production potentials per unit of nutrient absorbed $[85,86]$. In agroforestry systems, cacao is grown as an understory plant and subjected to rising $\left[\mathrm{CO}_{2}\right]$ and low levels of PPFD. Under such situations cacao genotypes that have high nutrient use efficiency for essential nutrients might be able to grow well and produce higher yields. Deficiencies of $\mathrm{P}, \mathrm{Ca}, \mathrm{Mg}, \mathrm{Zn}$ and Fe have been widely reported in soils of cacao growing regions of the world $[11,48,50]$. Cabala-Rosand et al. [50] state that under field conditions the most common deficiencies noted in cacao are N, K, Zn, Fe and B. P is also a limiting nutrient in almost all soils under cacao [49]. Genotypes that have high NUE for any of these nutrients could improve the sustainability and productivity of cacao grown in nutrient deficient soils under agroforestry systems. Amaz 15 was most efficient in NUE for N, K, Ca, B, Cu and Fe and SCA 6 was most efficient for P and K. Since Amaz15 had the longest root length among the cacao genotypes tested, this probably helped it to acquire more nutrients. Barber [89] states that the quantity of a nutrient taken up by a plant depends on the configuration and growth rate of the roots. Irrespective of levels of PPFD, increasing $\left[\mathrm{CO}_{2}\right]$ from 400 to $700 \mu \mathrm{mol} \mathrm{mol}^{-1}$ significantly increased NUE for all nutrients. In cacao Comum, Baligar et al. [35] reported that NUE for $\mathrm{N}, \mathrm{Mg}$, $\mathrm{Cu}, \mathrm{Mn}$ and $\mathrm{Zn}$ increased with increasing $\left[\mathrm{CO}_{2}\right]$ from 380 to $700 \mu \mathrm{mol} \mathrm{mol}^{-1}$. Irrespective of levels of $\left[\mathrm{CO}_{2}\right]$, increasing PPFD significantly affected NUE for $\mathrm{K}, \mathrm{Ca}, \mathrm{Mg}, \mathrm{B}$ and $\mathrm{Mn}$. With the exceptions of $\mathrm{N}$ and $\mathrm{Fe}$, increasing levels of PPFD from 100 to $400 \mu \mathrm{mol} \mathrm{m}{ }^{-2} \mathrm{~s}^{-1}$ increased NUE for all other nutrients. \%clearpage

Table 7. The effect of $\left[\mathrm{CO}_{2}\right]$ and photosynthetic photon flux density (PPFD) on macro-micro nutrient use efficiency (NUE) of seven cacao genotypes.

\begin{tabular}{|c|c|c|c|c|c|c|c|c|c|c|c|}
\hline \multirow{2}{*}{$\begin{array}{c}\mathrm{CO}_{2} \\
(\mu \mathrm{mol} \\
\left.\mathrm{mol}^{-1}\right)\end{array}$} & \multirow{2}{*}{$\begin{array}{c}\text { PPFD } \\
(\mu \mathrm{mol} \\
\left.\mathrm{m}^{-2} \mathrm{~s}^{-1}\right)\end{array}$} & $\mathbf{N}$ & $\mathbf{P}$ & $\mathbf{K}$ & $\mathrm{Ca}$ & Mg & B & $\mathrm{Cu}$ & $\mathbf{F e}$ & Mn & $\mathrm{Zn}$ \\
\hline & & \multicolumn{5}{|c|}{ mg shoot mg element ${ }^{-1}$} & \multicolumn{5}{|c|}{ mg shoot mg element ${ }^{-1}\left(\times 10^{4}\right)$} \\
\hline & & \multicolumn{10}{|c|}{ Catongo } \\
\hline \multirow[t]{3}{*}{400} & 100 & 36.64 & 225.8 & 65.68 & 63.39 & 147.6 & 2.92 & 4.17 & 1.66 & 1.30 & 2.48 \\
\hline & 200 & 34.70 & 237.9 & 69.06 & 64.09 & 148.4 & 2.92 & 4.48 & 1.93 & 1.65 & 2.76 \\
\hline & 400 & 31.90 & 199.4 & 65.34 & 65.25 & 157.8 & 3.09 & 4.06 & 1.16 & 1.82 & 1.96 \\
\hline \multirow[t]{4}{*}{700} & 100 & 38.72 & 251.6 & 63.67 & 67.89 & 161.8 & 3.60 & 5.39 & 5.61 & 1.62 & 3.02 \\
\hline & 200 & 41.53 & 278.1 & 75.12 & 74.38 & 154.9 & 4.20 & 5.68 & 5.95 & 2.07 & 2.87 \\
\hline & 400 & 37.31 & 272.1 & 77.24 & 78.29 & 181.1 & 4.10 & 5.88 & 7.15 & 2.25 & 2.79 \\
\hline & & \multicolumn{10}{|c|}{ Coca 3370} \\
\hline \multirow[t]{3}{*}{400} & 100 & 37.12 & 268.3 & 68.02 & 67.67 & 125.8 & 3.27 & 4.78 & 1.96 & 0.93 & 1.70 \\
\hline & 200 & 39.28 & 249.4 & 67.24 & 66.21 & 120.8 & 3.01 & 5.03 & 1.99 & 1.36 & 2.45 \\
\hline & 400 & 35.69 & 259.7 & 77.94 & 72.05 & 134.2 & 3.43 & 4.72 & 1.50 & 1.63 & 2.45 \\
\hline \multirow[t]{4}{*}{700} & 100 & 38.28 & 241.4 & 77.91 & 72.07 & 142.4 & 4.15 & 5.75 & 1.22 & 1.56 & 2.42 \\
\hline & 200 & 40.30 & 231.3 & 77.07 & 74.78 & 128.0 & 4.20 & 5.39 & 5.52 & 1.64 & 2.10 \\
\hline & 400 & 41.19 & 261.8 & 89.69 & 86.28 & 162.7 & 5.22 & 5.79 & 3.04 & 2.74 & 2.20 \\
\hline & & \multicolumn{10}{|c|}{ CCN 51} \\
\hline \multirow[t]{3}{*}{400} & 100 & 34.69 & 231.5 & 73.65 & 69.91 & 157.3 & 3.36 & 4.54 & 3.88 & 1.36 & 1.84 \\
\hline & 200 & 36.23 & 228.9 & 67.75 & 64.22 & 138.4 & 3.30 & 4.46 & 2.31 & 1.49 & 2.13 \\
\hline & 400 & 33.92 & 242.6 & 66.93 & 72.79 & 160.5 & 3.72 & 4.12 & 2.53 & 2.39 & 2.44 \\
\hline \multirow[t]{3}{*}{700} & 100 & 40.10 & 231.9 & 72.30 & 60.80 & 147.9 & 4.02 & 4.61 & 5.90 & 1.28 & 1.38 \\
\hline & 200 & 40.63 & 276.5 & 78.26 & 72.04 & 153.4 & 4.89 & 5.69 & 3.77 & 1.84 & 1.99 \\
\hline & 400 & 40.44 & 268.5 & 87.37 & 74.67 & 159.6 & 4.37 & 5.27 & 2.58 & 2.13 & 1.86 \\
\hline
\end{tabular}


Table 7. Cont.

\begin{tabular}{|c|c|c|c|c|c|c|c|c|c|c|c|}
\hline \multirow{2}{*}{$\begin{array}{c}\mathrm{CO}_{2} \\
(\mu \mathrm{mol} \\
\left.\mathrm{mol}^{-1}\right)\end{array}$} & \multirow{2}{*}{$\begin{array}{c}\text { PPFD } \\
(\mu \mathrm{mol} \\
\left.\mathrm{m}^{-2} \mathrm{~s}^{-1}\right)\end{array}$} & $\mathbf{N}$ & $\mathbf{P}$ & $\mathbf{K}$ & $\mathrm{Ca}$ & Mg & B & $\mathrm{Cu}$ & $\mathrm{Fe}$ & Mn & $\mathrm{Zn}$ \\
\hline & & \multicolumn{5}{|c|}{ mg shoot mg element $^{-1}$} & \multicolumn{5}{|c|}{ mg shoot mg element ${ }^{-1}\left(\times 10^{4}\right)$} \\
\hline & & \multicolumn{10}{|c|}{ Amaz 15} \\
\hline \multirow[t]{3}{*}{400} & 100 & 40.30 & 245.1 & 74.18 & 73.78 & 145.2 & 3.86 & 5.79 & 2.31 & 1.48 & 2.17 \\
\hline & 200 & 39.77 & 237.0 & 70.65 & 64.27 & 128.7 & 3.27 & 5.23 & 2.42 & 1.66 & 2.35 \\
\hline & 400 & 39.24 & 274.6 & 83.95 & 73.26 & 148.7 & 3.62 & 5.10 & 3.41 & 2.09 & 1.52 \\
\hline \multirow[t]{4}{*}{700} & 100 & 43.18 & 248.5 & 75.97 & 71.01 & 135.0 & 4.43 & 6.23 & 6.98 & 1.49 & 2.33 \\
\hline & 200 & 45.43 & 267.4 & 88.61 & 83.42 & 149.5 & 5.30 & 6.88 & 5.51 & 2.09 & 2.49 \\
\hline & 400 & 46.58 & 287.7 & 98.15 & 89.34 & 168.2 & 5.31 & 6.84 & 6.51 & 2.12 & 2.60 \\
\hline & & \multicolumn{10}{|c|}{ LCT EEN 37A } \\
\hline \multirow[t]{3}{*}{400} & 100 & 37.48 & 225.5 & 57.68 & 59.53 & 148.9 & 3.29 & 4.22 & 1.54 & 1.38 & 1.80 \\
\hline & 200 & 32.55 & 196.9 & 59.22 & 62.49 & 128.6 & 3.06 & 2.54 & 0.97 & 1.79 & 1.71 \\
\hline & 400 & 31.56 & 214.4 & 62.76 & 67.34 & 144.8 & 3.16 & 3.48 & 3.51 & 2.26 & 2.21 \\
\hline \multirow[t]{4}{*}{700} & 100 & 44.72 & 247.3 & 70.29 & 73.32 & 156.3 & 4.56 & 5.96 & 3.29 & 1.76 & 2.09 \\
\hline & 200 & 41.04 & 281.4 & 74.51 & 74.78 & 173.1 & 4.89 & 6.41 & 3.23 & 1.84 & 2.12 \\
\hline & 400 & 42.89 & 242.1 & 87.86 & 69.45 & 151.2 & 4.92 & 5.79 & 2.33 & 2.36 & 2.21 \\
\hline & \multicolumn{11}{|c|}{$\mathrm{Na} 33$} \\
\hline \multirow[t]{3}{*}{400} & 100 & 43.36 & 263.8 & 72.64 & 63.22 & 162.9 & 3.23 & 4.89 & 1.83 & 1.25 & 1.55 \\
\hline & 200 & 38.37 & 255.8 & 75.40 & 56.95 & 151.3 & 2.95 & 4.45 & 1.30 & 1.58 & 1.70 \\
\hline & 400 & 35.51 & 275.2 & 69.11 & 71.28 & 164.9 & 2.96 & 4.88 & 1.71 & 2.24 & 1.76 \\
\hline \multirow[t]{4}{*}{700} & 100 & 41.99 & 275.1 & 67.63 & 59.79 & 154.1 & 3.38 & 5.54 & 2.05 & 1.61 & 1.98 \\
\hline & 200 & 45.18 & 280.3 & 89.83 & 69.01 & 170.6 & 5.73 & 5.82 & 3.18 & 1.94 & 2.04 \\
\hline & 400 & 48.19 & 285.7 & 96.05 & 78.54 & 174.4 & 4.65 & 5.71 & 2.28 & 2.59 & 1.98 \\
\hline & \multicolumn{11}{|c|}{ SCA 6} \\
\hline \multirow[t]{3}{*}{400} & 100 & 40.55 & 298.8 & 74.55 & 73.21 & 159.9 & 3.44 & 6.26 & 1.79 & 1.33 & 2.30 \\
\hline & 200 & 39.39 & 294.3 & 71.30 & 64.75 & 145.4 & 3.26 & 5.08 & 1.23 & 1.49 & 1.83 \\
\hline & 400 & 35.60 & 276.7 & 76.83 & 72.10 & 153.3 & 3.00 & 4.55 & 2.02 & 1.61 & 2.39 \\
\hline \multirow[t]{3}{*}{700} & 100 & 45.30 & 306.8 & 74.11 & 69.89 & 158.7 & 4.49 & 6.47 & 3.56 & 1.49 & 2.22 \\
\hline & 200 & 45.17 & 351.9 & 98.11 & 84.87 & 184.6 & 5.44 & 7.22 & 3.15 & 1.99 & 2.79 \\
\hline & 400 & 43.38 & 280.3 & 87.71 & 75.36 & 163.1 & 4.33 & 5.73 & 2.04 & 2.25 & 1.83 \\
\hline \multicolumn{12}{|c|}{ Significance } \\
\hline \multirow{3}{*}{\multicolumn{2}{|c|}{$\begin{array}{c}\text { Genotype }(\mathrm{G}) \\
{\left[\mathrm{CO}_{2}\right](\mathrm{C})} \\
\text { PPFD (P) }\end{array}$}} & $* *$ & $* *$ & $* *$ & $* *$ & $* *$ & $* *$ & $* *$ & $*$ & NS & $* *$ \\
\hline & & $* *$ & $* *$ & $* *$ & $* *$ & $* *$ & $* *$ & $* *$ & $* *$ & $* *$ & $*$ \\
\hline & & NS & NS & $* *$ & $* *$ & $* *$ & $*$ & NS & NS & $* *$ & NS \\
\hline
\end{tabular}

* ${ }^{* *}$ Significant at 0.05 and 0.01 levels of probability, respectively. NS = Not significant.

\section{Conclusions}

Under glasshouse conditions, elevated $\left[\mathrm{CO}_{2}\right]$ increased growth, physiology, nutrient uptake and use efficiency; however, low light decreased growth, photosynthesis and nutrient uptake of cacao genotypes. Intraspecific differences were found in the genotypes such that AMAZ 15 was the highest for many parameters and LCT EEN 37A was often the lowest. Na 33 had high Fe uptake which could be a problem on Fe limited soils, but further testing is needed. Higher WUE in increasing levels of $\left[\mathrm{CO}_{2}\right]$ should be considered in selection of cacao genotypes useful for drought prone areas to maintain cacao sustainability and improve yields.

Author Contributions: V.C.B. conceived the study and was in charge of overall direction and planning; M.K.E. carried out the experiment, collected data and performed statistical analysis; A.-A.F.A., Q.R.d.A. and D.A. assisted in selection of cacao genotypes and implementation of the experiment; Z.H. conducted plant analysis and assisted in implementation of the experiment. All authors contributed to writing of the manuscript. All authors have read and agreed to the published version of the manuscript.

Funding: This research received no external funding.

Institutional Review Board Statement: Not applicable.

Informed Consent Statement: Not applicable.

Data Availability Statement: Relevant data applicable to this research are within the paper. 
Acknowledgments: We thank Regina C. R. Machado and Martin Aitken of MARS Center for Cocoa Research Alimirante, Itajuipe, Bahia, Brazil for providing pods of different cacao genotypes.

Conflicts of Interest: The authors declare no conflict of interest.

\section{References}

1. Galyuon, I.K.A.; McDavid, C.R.; Lopez, F.B.; Spence, J.A. The effect of irradiance level on cocoa (Theobroma cacao L): I. Growth and leaf adaptations. Trop. Agric. (Trinidad) 1996, 73, 23-28.

2. Serrano, P.; Biehl, B. The effect of light luminous stress on the cocoa plant: Fluorometric measurements under experimental (laboratory) conditions and in the field. In Proceedings of the 12th International Cocoa Research Conference, Salvador, Bahia, Brazil, 17-23 November 1996; pp. 581-588.

3. Mielke, M.S.; De Almeida, A.-A.F.; Gomes, F.P. Photosynthetic traits of five neotropical rainforest tree species: Interactions between light response curves and leaf-to-air vapour pressure deficit. Braz. Arch. Biol. Technol. 2005, 48, 815-824. [CrossRef]

4. Daymond, A.J.; Tricker, P.J.; Hadley, P. Genotypic variation in photosynthesis in cacao is correlated with stomatal conductance and leaf nitrogen. Biol. Plant. 2011, 55, 99-104. [CrossRef]

5. Cunningham, R.K.; Burridge, J.C. The Growth of Cacao (Theobroma cacao) With and Without Shade: With one Figure in the Text. Ann. Bot. 1960, 24, 458-462. [CrossRef]

6. Beer, J.; Muschler, R.; Kass, D.; Somarriba, E. Shade management in coffee and cacao plantations. Agrofor. Syst. 1997, 38, 139-164. [CrossRef]

7. Zuidema, P.A.; Leffelaar, P.A.; Gerritsma, W.; Mommer, L.; Anten, N.P. A physiological production model for cocoa (Theobroma cacao): Model presentation, validation and application. Agric. Syst. 2005, 84, 195-225. [CrossRef]

8. Gattward, J.N.; Almeida, A.-A.F. Cacao tree responses to variation in water availability. In Cocoa: Cultivation, Research and Innovation; Souza Júnior, J.O., Ed.; EDITUS Pub.: Ilhéus, Brazil, 2018; pp. 59-84.

9. De Almeida, A.-A.F.; Valle, R.R. Ecophysiology of the cacao tree. Braz. J. Plant Physiol. 2007, 19, 425-448. [CrossRef]

10. Ahenkorah, Y.; Akrofi, G.S.; Adri, A.K. The end of the first cocoa shade and manurial experiment at the Cocoa Research Institute of Ghana. J. Hortic. Sci. 1974, 49, 43-51. [CrossRef]

11. Willson, K. Coffee, Cocoa and Tea; CABI Publishing: Wallingford, UK, 1999.

12. Wood, G.A.R.; Lass, R.A. Cocoa, 4th ed.; Blackwell Science: Oxford, UK, 2001.

13. Lahive, F.; Hadley, P.; Daymond, A.J. The physiological responses of cacao to the environment and the implications for climate change resilience. A review. Agron. Sustain. Dev. 2019, 39, 5. [CrossRef]

14. Alvim, P.; de Cacao, T. Ecophysiology of Tropical Crops; de Alvim, P.T., Kozlowski, T.T., Eds.; Academy Press: New York, NY, USA, 1977; pp. 279-313. [CrossRef]

15. Lobão, D.E.; Setenta, W.C.; de Lobão, E.S.P.; Curvelo, K.; Valle, R.R. Cacao cabruca: Sistema agrossilvicultural tropical. In Ciencia, Tecnologia e Manejo do Cacaueiro; Valle, R.R., Ed.; Grafica e Editoria Vital Ltd.: Ilheus, Brazil, 2007; pp. $290-323$.

16. Rice, R.A.; Greenberg, R. Cacao Cultivation and the Conservation of Biological Diversity. Ambio 2000, 29, 167-173. [CrossRef]

17. Tscharntke, T.; Clough, Y.; Bhagwat, S.A.; Buchori, D.; Faust, H.; Hertel, D.; Hölscher, D.; Juhrbandt, J.; Kessler, M.; Perfecto, I.; et al. Multifunctional shade-tree management in tropical agroforestry landscapes-A review. J. Appl. Ecol. 2011, 48, 619-629. [CrossRef]

18. Sambuichi, R.H.R.; Vidal, D.B.; Piasentin, F.B.; Jardim, J.G.; Viana, T.G.; Menezes, A.A.; Mello, D.L.N.; Ahnert, D.; Baligar, V.C Cabruca agroforests in southern Bahia, Brazil: Tree component, management practices and tree species conservation. Biodivers. Conserv. 2012, 21, 1055-1077. [CrossRef]

19. Acheampong, K.; Hadley, P.; Daymond, A.J. Photosynthetic activity and early growth of four cacao genotypes as influenced by different shade regimes under west african dry and wet season conditions. Exp. Agric. 2012, 49, 31-42. [CrossRef]

20. Saj, S.; Durot, C.; Sakouma, K.M.; Gamo, K.T.; Avana-Tientcheu, M.-L. Contribution of associated trees to long-term species conservation, carbon storage and sustainability: A functional analysis of tree communities in cacao plantations of Central Cameroon. Int. J. Agric. Sustain. 2017, 15, 282-302. [CrossRef]

21. Jagoret, P.; Ngnogue, H.T.; Malézieux, E.; Michel, I. Trajectories of cocoa agroforests and their drivers over time: Lessons from the Cameroonian experience. Eur. J. Agron. 2018, 101, 183-192. [CrossRef]

22. Nijmeijer, A.; Lauri, P.-E.; Harmand, J.-M.; Freschet, G.T.; Nieboukaho, J.-D.E.; Fogang, P.K.; Enock, S.; Saj, S. Long-term dynamics of cocoa agroforestry systems established on lands previously occupied by savannah or forests. Agric. Ecosyst. Environ. 2019, 275, 100-111. [CrossRef]

23. Schroth, G.; Krauss, U.; Gasparotto, L.; Aguilar, J.A.D.; Vohland, K. Pests and diseases in agroforestry systems of the humid tropics. Agrofor. Syst. 2000, 50, 199-241. [CrossRef]

24. Niether, W.; Armengot, L.; Andres, C.; Schneider, M.; Gerold, G. Shade trees and tree pruning alter throughfall and microclimate in cocoa (Theobroma cacao L.) production systems. Ann. For. Sci. 2018, 75, 38. [CrossRef]

25. Abdulai, I.; Jassogne, L.; Graefe, S.; Asare, R.; Van Asten, P.; Läderach, P.; Vaast, P. Characterization of cocoa production, income diversification and shade tree management along a climate gradient in Ghana. PLoS ONE 2018, 13, e0195777. [CrossRef]

26. Asare, R.; Markussen, B.; Asare, R.A.; Anim-Kwapong, G.; Ræbild, A. On-farm cocoa yields increase with canopy cover of shade trees in two agro-ecological zones in Ghana. Clim. Dev. 2018, 11, 435-445. [CrossRef] 
27. Raja Harun, R.M.; Kamariah, H.I. The effects of shading regimes on the growth of cocoa Seedlings (Theobroma cacao L.). Pertanika 1983, 6, 1-5.

28. Okali, D.U.U.; Owusu, J.K. Growth analysis and photosynthetic rates of cocoa (Theobroma cacao L.) seedlings in relation to varying shade and nutrient regimes. Ghana J. Agric. Sci. 1975, 8, 51-67.

29. Hartemink, A.E. Nutrient Stocks, Nutrient Cycling, and Soil Changes in Cocoa Ecosystems: A Review. Adv. Agron. 2005, 86, 227-253. [CrossRef]

30. Baligar, V.C.; Bunce, J.A.; Machado, R.C.R.; Elson, M.K. Photosynthetic photon flux density, carbon dioxide concentration, and vapor pressure deficit effects on photosynthesis in cacao seedlings. Photosynthetica 2008, 46, 216-221. [CrossRef]

31. Bastide, P.; Jimmy, I. Gas transfer measurements on young cocoa trees in field and modeling of photosynthetic activity. In Proceedings of the 14th International Cocoa Research Conference, Accra, Ghana, 13-18 October 2003; pp. $195-203$.

32. Hutcheon, W.V. Photosynthesis of cocoa: Photosynthesis in relation to the light and plant nutrient status. In Report Cocoa Res. Inst. Ghana, 1973-1974; 1976; pp. 186-188.

33. Raja Harun, R.M.; Hardwick, K. The effects of prolonged exposure to different light intensities on the photosynthesis of cocoa leaves. In Proceedings of the 10th International Cocoa Research Conference, Santo Domingo, Dominican Republic, 17-23 May 1987; pp. 205-209.

34. Miyaji, K.-I.; Da Silva, W.S.; Alvim, P.D.T. Longevity of leaves of a tropical tree, Theobroma cacao, grown under shading, in relation to position within the canopy and time of emergence. New Phytol. 1997, 135, 445-454. [CrossRef]

35. Baligar, V.C.; Bunce, J.A.; Bailey, B.A.; Machado, R.C.; Pomella, A.W.V. Carbon dioxide and photosynthetic photon flux density effects on growth and mineral uptake of cacao. J. Food Agric. Environ. 2005, 3, 142-147. [CrossRef]

36. Gommers, C.M.; Visser, E.J.; Onge, K.R.S.; Voesenek, L.A.; Pierik, R. Shade tolerance: When growing tall is not an option. Trends Plant Sci. 2013, 18, 65-71. [CrossRef] [PubMed]

37. Fiorucci, A.-S.; Fankhauser, C. Plant Strategies for Enhancing Access to Sunlight. Curr. Biol. 2017, 27, R931-R940. [CrossRef]

38. Van Vuuren, D.P.; Edmonds, J.; Kainuma, M.; Riahi, K.; Thomson, A.; Hibbard, K.; Hurtt, G.C.; Kram, T.; Krey, V.; Lamarque, J.-F.; et al. The representative concentration pathways: An overview. Clim. Chang. 2011, 109, 5-31. [CrossRef]

39. IPCC. Climate Change 2014: Synthesis Report. In Contribution of Working Groups I, II and III the Fifth Assessment Report of the Intergovernmental Panel on Climate Change; Core Writing Team, Pachauri, R.K., Meyer, L.A., Eds.; IPCC: Geneva, Switzerland, 2014; $151 \mathrm{p}$.

40. Amthor, J.S. Terrestrial higher-plant response to increasing atmospheric $\left[\mathrm{CO}_{2}\right]$ in relation to the global carbon cycle. Glob. Chang. Biol. 1995, 1, 243-274. [CrossRef]

41. Galyuon, I.K.A.; McDavid, C.R.; Lopez, F.B.; Spence, J.A. The effect of irradiance level on cocoa (Theobroma cacao L): II. Gas exchange and chlorophyll fluorescence. Trop. Agric. (Trinidad) 1996, 73, $29-33$.

42. Miyaji, K.-I.; Da Silva, W.S.; Alvim, P.D.T. Productivity of leaves of a tropical tree, Theobroma cacao, grown under shading, in relation to leaf age and light conditions within the canopy. New Phytol. 1997, 137, 463-472. [CrossRef]

43. Wullschleger, S.D.; Gunderson, C.A.; Hanson, P.J.; Wilson, K.B.; Norby, R.J. Sensitivity of stomatal and canopy conductance to elevated $\mathrm{CO}_{2}$ concentration-Interacting variables and perspectives of scale. New Phytol. 2002, 153, 485-496. [CrossRef]

44. Long, S.P.; Ainsworth, E.A.; Rogers, A.; Ort, D.R. Rising atmospheric carbon dioxide: Plants face the Future. Annu. Rev. Plant Biol. 2004, 55, 591-628. [CrossRef] [PubMed]

45. Branco, M.C.D.S.; Baligar, V.C.; De Almeida, A.-A.F.; Dalmolin, Â.C.; Ahnert, D. Influence of low light intensity and soil flooding on cacao physiology. Sci. Hortic. 2017, 217, 243-257. [CrossRef]

46. Lahive, F.; Hadley, P.; Daymond, A.J. The impact of elevated $\mathrm{CO}_{2}$ and water deficit stress on growth and photosynthesis of juvenile cacao (Theobroma cacao L.). Photosynthetica 2017, 56, 911-920. [CrossRef]

47. Hebbar, K.B.; Apshara, E.; Chandran, K.P.; Prasad, P.V.V. Effect of elevated $\mathrm{CO}_{2}$, high temperature, and water deficit on growth, photosynthesis, and whole plant water use efficiency of cocoa (Theobroma cacao L.). Int. J. Biometeorol. 2020, 64, 47-57. [CrossRef] [PubMed]

48. Cunningham, R.K. Micro-nutrient deficiency in cacao in Ghana. Emp. J. Exp. Agric. 1964, 32, 42-50.

49. Ahenkorah, Y. Influence of environment on growth and production of the cacao tree: Soils and nutrition. In Proceeding of the 7th International Cocoa Research Conference, Douala, Cameroon, 4-12 November 1979; pp. 167-176.

50. Cabala-Rosand, P.; Santana, M.B.M.; de Santana, C.J.L. Cacao. In Detecting Mineral Nutrient Deficiencies in Tropical and Temperate Crops; Plucknett, D.L., Sprague, H.B., Eds.; Westview Tropical Agriculture Series; Westview Press: Boulder, CO, USA, 1989; pp. 409-425.

51. Clark, R.B.; Baligar, V.C. Acidic and alkaline soil constraints in plant mineral nutrition. In Plant Environment Interactions II; Wilkinson, R.E., Ed.; Marcel Dekker Publ.: New York, NY, USA, 2000; pp. 133-177.

52. Hartemink, A.E. Soil Fertility Decline in the Tropics: With Case Studies on Plantations; CABI Publishing: Wallingford, UK, 2003. [CrossRef]

53. Yapp, J.H.H.; Hadley, P. Inter-relationships between canopy architecture, light interception, vigor and yield in cocoa: Implications for improving production efficiency. In Proceedings of the International Cocoa Conference: Challenges in the 90's, Kuala Lumpur, Malaysia, 25-28 September 1991; Malaysian Cocoa Board: Kuala Lumpur, Malaysia, 1994; pp. 332-350.

54. Motamayor, J.C.; Lachenaud, P.; Mota, J.W.D.S.E.; Loor, R.; Kuhn, D.N.; Brown, J.S.; Schnell, R.J. Geographic and Genetic Population Differentiation of the Amazonian Chocolate Tree (Theobroma cacao L.). PLoS ONE 2008, 3, e3311. [CrossRef] [PubMed] 
55. Daymond, A.J.; Hadley, P.; Machado, R.C.R.; Ng, E. Canopy characteristics of contrasting clones of cacao (theobroma cacao). Exp. Agric. 2002, 38, 359-367. [CrossRef]

56. Bartley, B.G.D. The Genetic Diversity of Cacao and its Utilization; CABI Publishing: Wallingford, UK, 2005.

57. Turnbull, C.J.; Hadley, P. International Cocoa Germplasm Database (ICGD); CRA Ltd./ICE Futures Europe/University of Reading: Reading, UK, 2015; Available online: http:/ / www.icgd.reading.ac.uk (accessed on 22 May 2020).

58. Ahnert, D.; Eskes, A.B. Developments in cacao breeding programmes in Africa and the Americas. In Achieving Sustainable Cultivation of Cocoa; Umaharan, P., Ed.; Burleigh Dodds Science Publishing: Cambridge, UK, 2018; pp. 1-40. [CrossRef]

59. USEPA. Method 200.7, Rev. 5.0, Trace Elements in Water, Solids, and Biosolids by Inductively Coupled Plasma-Atomic Emission Spectrometry; USEPA, Office of Science and Technology: Washington, DC, USA, 2001.

60. Bremner, J.M. Nitrogen Total. In Methods of Soil Analysis, Part 3 Chemical Methods; Sparks, D.L., Ed.; SSSA: Madison, WI, USA, 1996; pp. 1085-1122. [CrossRef]

61. De Araújo, R.P.; De Almeida, A.-A.F.; Barroso, J.P.; De Oliveira, R.A.; Gomes, F.P.; Ahnert, D.; Baligar, V. Molecular and morphophysiological responses cocoa leaves with different concentrations of anthocyanin to variations in light levels. Sci. Hortic. 2017, 224, 188-197. [CrossRef]

62. Baligar, V.C.; Elson, M.; He, Z.L.; Li, Y.; Paiva, A.D.Q.; Ahnert, D.; Almeida, A.-A.F.; Fageria, N.K. Ambient and Elevated Carbon Dioxide on Growth, Physiological and Nutrient Uptake Parameters of Perennial Leguminous Cover Crops under Low Light Intensities. Int. J. Plant Soil Sci. 2017, 15, 1-16. [CrossRef]

63. Baligar, V.C.; Elson, M.K.; He, Z.L.; Li, Y.; Paiva, A.D.Q.; Ahnert, D.; Almeida, A.-A.F. Growth, Physiological and Nutrient Uptake Traits of Crotalaria Cover Crops Influenced by Levels of Carbon Dioxide under Low Light Intensities. Int. J. Plant Soil Sci. 2018, 23, 1-14. [CrossRef]

64. Hollinger, D.Y. Gas exchange and dry matter allocation responses to elevation of atmospheric $\mathrm{CO}_{2}$ concentration in seedlings of three tree species. Tree Physiol. 1987, 3, 193-202. [CrossRef]

65. Poorter, $\mathrm{H}$. Interspecific variation in the growth response of plants to an elevated ambient $\mathrm{CO}_{2}$ concentration. Vegetatio 1993, 104, 77-97. [CrossRef]

66. Bunce, J. Variation in growth stimulation by elevated carbon dioxide in seedlings of some C3 crop and weed species. Glob. Chang. Biol. 1997, 3, 61-66. [CrossRef]

67. Sefcik, L.T.; Zak, D.R.; Ellsworth, D.S. Photosynthetic responses to understory shade and elevated carbon dioxide concentration in four northern hardwood tree species. Tree Physiol. 2006, 26, 1589-1599. [CrossRef] [PubMed]

68. Ellsworth, D.S.; Thomas, R.; Crous, K.Y.; Palmroth, S.; Ward, E.; Maier, C.; DeLucia, E.; Oren, R. Elevated $\mathrm{CO}_{2}$ affects photosynthetic responses in canopy pine and subcanopy deciduous trees over 10 years: A synthesis from Duke FACE. Glob. Chang. Biol. 2011, 18, 223-242. [CrossRef]

69. Cure, J.D.; Acock, B. Crop responses to carbon dioxide doubling: A literature survey. Agric. For. Meteorol. 1986, 38, 127-145. [CrossRef]

70. Kimball, B.; Kobayashi, K.; Bindi, M. Responses of Agricultural Crops to Free-Air $\mathrm{CO}_{2}$ Enrichment. Adv. Agron. 2002, 77, 293-368. [CrossRef]

71. Yan, W.; Zhong, Y.; Shangguan, Z. A meta-analysis of leaf gas exchange and water status responses to drought. Sci. Rep. 2016, 6, 20917. [CrossRef] [PubMed]

72. Prior, S.A.; Runion, G.B.; Marble, S.C.; Rogers, H.H.; Gilliam, C.H.; Torbert, H.A. A Review of Elevated Atmospheric CO 2 Effects on Plant Growth and Water Relations: Implications for Horticulture. HortScience 2011, 46, 158-162. [CrossRef]

73. Schneider, M.; Andres, C.; Trujillo, G.; Alcon, F.; Amurrios, P.; Perez, E.; Weibel, F.; Milz, J. Cocoa and total system yields of organic and conventional agroforestry vs. monoculture systems in a long-term field trial in Bolivia. Exp. Agric. 2016, 53, 351-374. [CrossRef]

74. Ainsworth, E.A.; Long, S.P. What have we learned from 15 years of free-air $\mathrm{CO}_{2}$ enrichment (FACE)? A meta-analytic review of the responses of photosynthesis, canopy properties and plant production to rising $\mathrm{CO}_{2}$. New Phytol. 2004, 165, 351-372. [CrossRef]

75. Eamus, D. The interaction of rising $\mathrm{CO}_{2}$ and temperatures with water use efficiency. Plant Cell Environ. 1991, 14, 843-852. [CrossRef]

76. Medrano, H.; Tomás, M.; Martorell, S.; Flexas, J.; Hernández, E.; Rosselló, J.; Pou, A.; Escalona, J.-M.; Bota, J. From leaf to whole-plant water use efficiency (WUE) in complex canopies: Limitations of leaf WUE as a selection target. Crop. J. 2015, 3, 220-228. [CrossRef]

77. Laderach, P.; Eitzinger, A.; Martinez, A.; Castro, N. Predicting the Impact of Climate Change on the Cocoa-Growing Regions in Ghana and Cote d'Ivoire; CIAT: Managua, Nicaragua, 2011; Available online: http://www.eenews.net/assets/2011/10/03/document_ cw_01.pdf (accessed on 6 November 2020).

78. Schroth, G.; Läderach, P.; Martinez-Valle, A.I.; Bunn, C.; Jassogne, L. Vulnerability to climate change of cocoa in West Africa: Patterns, opportunities and limits to adaptation. Sci. Total. Environ. 2016, 556, 231-241. [CrossRef] [PubMed]

79. Gateau-Rey, L.; Tanner, E.V.J.; Rapidel, B.; Marelli, J.-P.; Royaert, S. Climate change could threaten cocoa production: Effects of 2015-16 El Niño-related drought on cocoa agroforests in Bahia, Brazil. PLoS ONE 2018, 13, e0200454. [CrossRef] [PubMed]

80. Snoeck, J. Cacao. In Plant Analysis as a Guide to the Nutrient Requirements of Temperate and Tropical Crops; Martin-Prevel, P., Gagnard, J., Gautier, P., Jones, J.B., Jr., Holmes, M.R.J., Eds.; Lavoisier: New York, NY, USA, 1984; pp. 432-439. 
81. Bhargava, B.S.; Raghupathi, H. Analysis of plant materials for macro and micronutrients. In Methods of Analysis of Soils, Plants, Waters and Fertilisers; Tandon, H.L.S., Ed.; FDCO: New Delhi, India, 1993; pp. 49-82.

82. Dong, J.; Gruda, N.; Lam, S.K.; Li, X.; Duan, Z. Effects of Elevated $\mathrm{CO}_{2}$ on Nutritional Quality of Vegetables: A Review. Front. Plant Sci. 2018, 9, 924. [CrossRef]

83. Schaffer, B.; Whiley, A.W.; Searle, C.; Nissen, R.J. Leaf Gas Exchange, Dry Matter Partitioning, and Mineral Element Concentrations in Mango as Influenced by Elevated Atmospheric Carbon Dioxide and Root Restriction. J. Am. Soc. Hortic. Sci. 1997, 122, 849-855. [CrossRef]

84. Baligar, V.C.; Fageria, N.K.; Paiva, A.Q.; Silveira, A.; Pomella, A.W.V.; Machado, R.C.R. Light Intensity Effects on Growth and Micronutrient Uptake by Tropical Legume Cover Crops. J. Plant Nutr. 2006, 29, 1959-1974. [CrossRef]

85. Gerloff, G.C.; Gabelman, W.H. Genetic basis of inorganic plant nutrition. In Inorganic Plant Nutrition; Lauchli, A., Bielski, R.L., Eds.; Springer: New York, NY, USA, 1983; pp. 453-480.

86. Vose, P.B. Effects of genetic factors on nutritional requirements of plants. In Crop Breeding: A Contemporary Basis; Vose, P.B., Blixt, S.G., Eds.; Pergamon Press: Oxford, UK, 1984; pp. 67-114. [CrossRef]

87. Baligar, V.C.; Duncan, R.R. (Eds.) Crops as Enhancers of Nutrient Use; Academic Press: San Diego, CA, USA, 1990.

88. Baligar, V.C.; Fageria, N.K.; He, Z.L. Nutrient Use Efficiency in Plants. Commun. Soil Sci. Plant Anal. 2001, 32, 921-950. [CrossRef]

89. Barber, S.A. Soil Nutrient Bioavailability: A Mechanistic Approach; John Wiley \& Sons: New York, NY, USA, 1995. 